NASA/TM-1999-208900

AIAA-99-0094

\title{
Parametric Experimental Study of the Formation of Glaze Ice Shapes on Swept Wings
}

Mario Vargas

Glenn Research Center, Cleveland, Ohio

Eli Reshotko

Case Western Reserve University, Cleveland, Ohio 
Since its founding, NASA has been dedicated to the advancement of aeronautics and space science. The NASA Scientific and Technical Information (STI) Program Office plays a key part in helping NASA maintain this important role.

The NASA STI Program Office is operated by Langley Research Center, the Lead Center for NASA's scientific and technical information. The NASA STI Program Office provides access to the NASA STI Database, the largest collection of aeronautical and space science STI in the world. The Program Office is also NASA's institutional mechanism for disseminating the results of its research and development activities. These results are published by NASA in the NASA STI Report Series, which includes the following report types:

- $\quad$ TECHNICAL PUBLICATION. Reports of completed research or a major significant phase of research that present the results of NASA programs and include extensive data or theoretical analysis. Includes compilations of significant scientific and technical data and information deemed to be of continuing reference value. NASA's counterpart of peerreviewed formal professional papers but has less stringent limitations on manuscript length and extent of graphic presentations.

- TECHNICAL MEMORANDUM. Scientific and technical findings that are preliminary or of specialized interest, e.g., quick release reports, working papers, and bibliographies that contain minimal annotation. Does not contain extensive analysis.

- CONTRACTOR REPORT. Scientific and technical findings by NASA-sponsored contractors and grantees.
- CONFERENCE PUBLICATION. Collected papers from scientific and technical conferences, symposia, seminars, or other meetings sponsored or cosponsored by NASA.

- SPECIAL PUBLICATION. Scientific, technical, or historical information from NASA programs, projects, and missions, often concerned with subjects having substantial public interest.

- TECHNICAL TRANSLATION. Englishlanguage translations of foreign scientific and technical material pertinent to NASA's mission.

Specialized services that complement the STI Program Office's diverse offerings include creating custom thesauri, building customized data bases, organizing and publishing research results ... even providing videos.

For more information about the NASA STI Program Office, see the following:

- Access the NASA STI Program Home Page at http://www.sti.nasa.gov

- E-mail your question via the Internet to help@sti.nasa.gov

- Fax your question to the NASA Access Help Desk at (301) 621-0134

- Telephone the NASA Access Help Desk at (301) 621-0390

- Write to:

NASA Access Help Desk

NASA Center for AeroSpace Information 7121 Standard Drive

Hanover, MD 21076 
NASA/TM-1999-208900

AIAA-99-0094

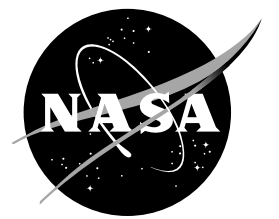

\section{Parametric Experimental Study of the Formation of Glaze Ice Shapes on Swept Wings}

Mario Vargas

Glenn Research Center, Cleveland, Ohio

Eli Reshotko

Case Western Reserve University, Cleveland, Ohio

Prepared for the

37th Aerospace Sciences Meeting \& Exhibit

sponsored by the American Institute of Aeronautics and Astronautics

Reno, Nevada, January 11-14, 1999

National Aeronautics and

Space Administration

Glenn Research Center 


\section{Acknowledgments}

The authors would like to thank Mr. William Sexton, Mr. Dave Sheldon and all the personnel at the Icing Research Tunnel for their help in all phases of the experiment; Mrs. Tammy Langhals for her help with ice shape tracings; and the personnel of the Imaging Technology Center for their assistance with the photographic work.

Available from

NASA Center for Aerospace Information 7121 Standard Drive

Hanover, MD 21076

Price Code: A03
National Technical Information Service 5285 Port Royal Road Springfield, VA 22100 Price Code: A03 


\title{
PARAMETRIC EXPERIMENTAL STUDY OF THE FORMATION OF GLAZE ICE SHAPES ON SWEPT WINGS
}

\author{
Mario Vargas* \\ National Aeronautics and Space Administration \\ Glenn Research Center \\ Cleveland, Ohio 44135 \\ and \\ Eli Reshotko ${ }^{\dagger}$ \\ Case Western Reserve University \\ Cleveland, Ohio 44106
}

\begin{abstract}
An experiment was conducted to study the effect of velocity and sweep angle on the critical distance in ice accretion formation on swept wings at glaze ice conditions. The critical distance is defined as the distance from the attachment line to the beginning of the zone where roughness elements develop into glaze ice feathers. Icing runs were performed on a NACA 0012 swept wing tip at velocities of 75, 100, 150, and 200 miles per hour. At each velocity and tunnel condition, the sweep angle was changed from $0^{\circ}$ to $45^{\circ}$ at $5^{\circ}$ increments. Casting data, ice shape tracings, and close-up photographic data were obtained. The results showed that at given velocity and tunnel conditions, as the sweep angle is increased from $0^{\circ}$ to $25^{\circ}$, the critical distance slowly decreases. As the sweep angle is increased past $25^{\circ}$, the critical distance starts decreasing more rapidly. For 75 and $100 \mathrm{mph}$ it reaches a value of 0 millimeters at $35^{\circ}$. For 150 and $200 \mathrm{mph}$ it reaches a value of 0 millimeters at $40^{\circ}$. On the ice accretion, as the sweep angle is increased from $0^{\circ}$ to $25^{\circ}$, the extent of the attachment line zone slowly decreases, and in the glaze ice feathers zone, the angle that the preferred direction of growth of the feathers makes with respect to the attachment line direction increases. But overall, the ice accretions remain similar to the

\footnotetext{
Aerospace Engineer, Icing Branch, NASA Lewis Research Center, Member AIAA

$\dagger$ Professor, Department of Mechanical and Aerospace Engineering, Fellow AIAA
}

Copyright () 1999 by the American Institute of Aeronautics and Astronautics, Inc. No copyright is asserted in the United States under Title 17, U.S. Code. The U.S. Government has a royaltyfree license to exercise all rights under the copyright claimed herein for Governmental Purposes. All other rights are reserved by the copyright owner.
\end{abstract}

$0^{\circ}$ sweep angle case. As the sweep angle is increased above $25^{\circ}$, the extent of the attachment line zone decreases rapidly and complete scallops form at $35^{\circ}$ sweep angle for 75 and $100 \mathrm{mph}$, and at $40^{\circ}$ for 150 and $200 \mathrm{mph}$.

\section{Nomenclature}

$\begin{array}{ll}\Lambda & \text { Sweep angle, degrees } \\ d_{c r} & \text { Critical distance, millimeters } \\ L W C & \text { Cloud liquid water content, } \mathrm{g} / \mathrm{m}^{3} \\ M V D & \text { Water droplet median volume diameter, } \\ & \mu \mathrm{m} \\ r & \text { Leading edge radius of airfoil, } \mathrm{m} \\ s & \begin{array}{l}\text { Distance from the attachment line, } \\ \text { millimeters }\end{array} \\ \tau & \text { Ice accretion time, minutes } \\ V_{\infty} & \text { Free stream velocity, } \mathrm{m} / \mathrm{s}\end{array}$

\section{Introduction}

Ice accretions on swept wings at glaze ice conditions can be classified as complete scallops, incomplete scallops, or no-scallops. Complete scallops or lobster tails are ice accretions that appear only on swept wings for certain conditions that favor glaze ice formations, and are characterized by a particular shape, height, and spacing. Incomplete scallops are ice shapes that also appear only on swept wings and where scallops tips form beginning at a given distance from the attachment line. No-scallops are ice accretions where no scallop tips develop. An understanding of the fundamental physical mechanisms and parameters involved in their formation is one of the areas of research in the Icing Branch at NASA Lewis Research Center. These studies of ice accretion formations on swept wings are needed to provide the fundamental data and physical understanding 
for the development of models that can be implemented into 3D ice accretion codes.

The presence of scallop formations on swept wings has been documented in past studies of ice accretions on swept wings $s^{1,2,3}$. Initial work to predict scallop formations using a 3D ice accretion code was done by Reehorst ${ }^{4}$. LEWICE 3D was modified and code predictions were compared to ice accretion flight data. Reehorst and Bidwell ${ }^{5}$ did an experiment in the NASA Lewis Icing Research Tunnel (IRT) to study the effect of tunnel parameters on the presence or absence of scallops. Hedde and Guffond $^{6}$ proposed a ballistic model of scallop growth.

A study of the fundamental physical mechanisms that lead to the formation of scallops on swept wings was conducted by Vargas and Reshotko, 8. They studied the formation of scallops on a NACA 0012 swept wing tip at $45^{\circ}, 30^{\circ}$, and $15^{\circ}$ sweep angles. They chose a baseline case and obtained direct measurements of scallop height and spacing, castings, video data and close-up photographic data. Their results showed that scallops and incomplete scallops are made of glaze ice feathers that grow from roughness elements that have reached a minimum height and are located beyond a given distance from the attachment line. This distance, called the critical distance $d_{c r}$, was found to depend on tunnel conditions and sweep angle for the airfoil tested. It determines if complete scallops, incomplete scallops or no-scallops are going to be formed. They also identified the mechanisms of growth for complete and incomplete scallops, studied the effect of velocity, temperature and LWC on scallop formation, and examined the possibility that cross flow instability may be the physical mechanism that triggers the growth of roughness elements into glaze ice feathers in scallop formation.

This report presents the results of an experimental investigation carried out in the lcing Research Tunnel (IRT) at NASA Lewis Research Center to study the effect of velocity and sweep angle on the critical distance $d_{c r}$. Icing runs were performed using a NACA 0012 swept wing tip that could be set at sweep angles from $0^{\circ}$ to $45^{\circ}$ at $5^{\circ}$ increments. Tunnel total temperature of $25^{\circ} \mathrm{F}, 0.75 \mathrm{~g} / \mathrm{m}^{3} \mathrm{LWC}$ and $20 \mu \mathrm{m}$ MVD were maintained for all tests. Runs were conducted for ice accretion times of 5 and 10 minutes. During the experiments, observations were also made of the ice accretions formed on the end cap of the airfoil. These observations allowed study of the growth of roughness elements into glaze ice feathers with a preferred direction of growth, and the formation of scallops at high local sweep angles.

\section{Experimental Procedure}

\section{Icing Research Tunnel}

Figure 1 shows the Icing Research Tunnel. The IRT is a closed-loop refrigerated wind tunnel with a test section 1.8 meters ( 6 feet) high, 2.7 meters ( 9 feet) wide and 6.0 meters (20 feet) long. The total air temperature in the test section can be varied between $-30^{\circ} \mathrm{C}\left(-20^{\circ} \mathrm{F}\right)$ and $+1{ }^{\circ} \mathrm{C}\left(+33^{\circ} \mathrm{F}\right)$ within $\pm 0.5^{\circ} \mathrm{C}\left( \pm 1^{\circ} \mathrm{F}\right)$. Velocities up to $160 \mathrm{~m} / \mathrm{s}$ (350 mph) can be obtained with a blockage of $5 \%$ in the test section. A spray system allows control of the liquid water content (LWC) between 0.2 to 3.0 grams per cubic meter. The spray nozzles provide droplet median volume diameters (MVD) from 15 to $40 \mu \mathrm{m}$.

\section{Model}

The model chosen for this study was a NACA 0012 Swept Wing Tip (figure 2). The airfoil is made of wood, with a 0.381 meter (15 inch) chord measured normal to the leading edge, and a 0.609 meter (24 inch) span. It is mounted in the tunnel on a stand that allows pivoting of the airfoil to sweep angles of $0^{\circ}$ to $45^{\circ}$ at $5^{\circ}$ increments. The end of the airfoil is fitted with an end cap. For sweep angles larger than $30^{\circ}$ a small extension was fitted at the base of the airfoil to improve the airflow. A heater was installed on the area where the measurements and collection of ice shapes were going to be performed. A grid was painted on the surface of the heater to allow identification of the flow direction on the photographic data and to serve as a distance scale in some pictures.

\section{Castings}

For each one of the NACA 0012 icing runs, a urethane casting was made of the ice shape. The castings allowed measurement of the critical distance and observation of the ice accretion.

The castings were made by removing the ice shape from the airfoil using the heater, immersing the ice shape in a bath of bees-wax at $150{ }^{\circ} \mathrm{F}$ to form a wax mold, draining the water from inside the wax mold, and filling the mold with liquid urethane. 
The urethane was allowed to solidify, and then a solvent was used to remove the wax. Figure 3 shows a urethane casting of an ice accretion.

\section{Icing Measurements}

For each run, a set of measurements was also taken directly on the ice shape. The height of the ice accretion was measured at the attachment line location, the critical distance was measured, and a pencil tracing of the ice shape was made, always at the same location on the airfoil.

\section{Test Matrix for Icing Runs}

Table 1 and 2 list the test matrix for the icing runs at ice accretion times of 5 and 10 minutes respectively. For velocities of $75,100,150$, and 200 miles per hour, with other conditions the same as the base case, runs were conducted for sweep angles from $0^{\circ}$ to $45^{\circ}$ at $5^{\circ}$ increments.

\section{Test Procedure}

At the start of each run, the tunnel was brought to the target velocity and total temperature and the tunnel spray system was started. During the run the tunnel parameters were recorded using the NASA-Lewis Escort data acquisition system. Once the target ice accretion time was reached, the tunnel was brought to idle. After entering the tunnel, a measuring tape was placed around the ice shape, and photographic data was taken with a $35 \mathrm{~mm}$ camera following a predetermined sequence and location for the pictures. Then three cuts were made on the ice accretion to prepare the ice shape for removal. Following this, the icing measurements discussed above were taken directly on the ice accretion and general observations were recorded. The heater was activated and two samples of the ice shape were removed taking special care not to melt or damage the ice shape in the process. The removed ice shapes were taken to the casting area and bees-wax molds were made. The airfoil was cleaned before the next run.

\section{Results and Discussion}

\section{Background}

Previous studies on formation of ice accretions on swept wings at glaze ice conditions ${ }^{7,8}$ found that scallop and incomplete scallop formation is governed by local effects on roughness elements.
Roughness elements formed at the beginning of the ice accretion process develop into glaze ice feathers when they reach a given height, and are located beyond a given distance from the attachment line. This distance is called the critical distance $d_{c r}$, and it depends on sweep angle and tunnel conditions. When the critical distance is not zero it defines two zones on the ice accretion. A zone called the attachment line zone, where the roughness elements do not become feathers, and another zone called the glaze ice feathers zone where the roughness elements develop into feathers. The attachment line zone begins at the attachment line proper and extends on each side to the location where roughness elements develop into feathers (beginning of the glaze ice feathers zone). The glaze ice feathers zone begins at the end of the attachment line zone and extends some distance chordwise. Only feathers that are an active part of the main ice accretion are included in the definition of the glaze ice feathers zone. When the critical distance is zero only the glaze ice feathers zone is present.

The feathers in the glaze ice feathers zone are inclined into the flow. They have a tooth shape, and therefore a preferred direction of growth (the direction along which a feather is growing faster laterally, that is, the direction of the larger axis for the tooth shape of the top of the feather). The preferred direction of growth is oriented perpendicular to the external streamlines. The angle that the preferred direction of growth makes with respect to the attachment line direction is $90^{\circ}$ for feathers located on the attachment line (streamlines are parallel to the attachment line direction at this location). The angle decreases as the distance from the attachment line increases (the streamlines are turning as they move away from the location of the attachment line).

Three types of ice accretions were identified on swept wings at glaze ice conditions: complete scallops, incomplete scallops, and no-scallops.

When complete scallops form, the ice accretion is covered with glaze ice feathers with a preferred direction of growth that is perpendicular to the external streamlines. The feathers have developed from roughness elements that reached a certain height. The value of the critical distance is zero, and only the glaze ice feathers zone is present. The feathers join along the preferred direction of growth to form ridges, with incipient scallop tips 
formed by the feathers at the end of each ridge. As the ridges grow they form scallop tips. As the scallop tips grow in height and along the preferred direction, they merge with adjacent scallop tips by joining at the top of the feathers that form each scallop tip. This mechanism is responsible for the growth of the scallop tips, their increase in size, and the enhancing of the spacing between scallops. Along the attachment line area the feathers tend to join other feathers around them by touching, bridging and filling, in this way they form areas of solid ice that are also covered with roughness elements. As the scallop tips grow by joining at their tops, the top surface tends to fill with water and areas of solid ice can be observed with roughness elements present.

When the critical distance is not zero and only roughness elements located beyond a given distance from the attachment line grow to become feathers, incomplete scallops or no-scallops may develop. The formation of incomplete scallops or no-scallops depends on the angle that the preferred direction of growth of the feathers makes with respect to the attachment line direction.

When incomplete scallops form, the feathers in the glaze ice feathers zone will form scallop tips. The mechanisms of formation of these scallop tips were found to be identical to the mechanisms observed for the formation of the scallop tips in the complete scallop case. The formation of the scallop tips depends on the angle that the preferred direction of growth of the feathers makes with respect to the attachment line, which in turn depends on the distance from the attachment line at which those feathers are located. The angle must be large enough to allow the mechanisms of formation of scallop tips to operate and form scallop tips, and also must be large enough to prevent the ice of the attachment line zone from covering all the glaze ice feathers zone and burying the incipient scallop tips.

When no-scallops form, scallop tips are not present in the ice accretion. Three situations may lead to the formation of no-scallops. In one case the critical distance may be so large that only the attachment line zone is present. In the second case the attachment line zone and the glaze ice feathers zone are both present, but the angle of the feathers with respect to the attachment line direction is not large enough for the mechanisms of formation of scallop tips to operate. In the last case, the attachment line zone and the glaze ice feathers zone are both present, and the angle of the feathers with respect to the attachment line direction is large enough for the mechanisms of scallop tip formation to operate, but not large enough to prevent the ice of the attachment line from totally covering the scallop tips. When the feathers are totally covered they cease to play a role in the formation of the ice accretion.

When the attachment line zone and the glaze ice feathers zone are both present, in general one will tend to prevail over the other in the first stages of the formation of the ice accretion, and this will influence the final ice shape. This interaction between the ice of the attachment line zone and the feathers in the glaze ice feathers zone depends on how fast each kind of ice grows. In an incomplete scallop when the critical distance is small and the feathers in the glaze ice feathers zone grow faster than the ice of the attachment line, they will form large scallop tips. As ice accretion time increases the large scallop tips wash out the presence of the attachment line zone and the ice accretion looks almost like complete scallops. In a no-scallop, in some cases the feathers may grow faster than the attachment line ice in the beginning of the ice accretion, but the ice of the attachment line eventually will cover them and the feathers will cease to play a role in the formation of the ice shape. Because of the fast growth of the feathers in the initial stage of the formation of the ice accretion, the ice shape will show horns, and resemble some of the ice shapes that are observed in 2D ice accretions. In a noscallop when the ice of the attachment line rapidly covers the feathers and the feathers cease to play a role in the formation of the ice shape, the final ice accretion resemble some of the ice shapes observed in 2D ice accretions.

In all cases of formation of glaze ice accretions on a swept wing, the distance from the attachment line beyond which the roughness elements become glaze ice feathers (the critical distance $d_{c r}$ ) is a critical factor in the kind of ice accretion that will form.

The critical distance was found to be repeatable and fairly constant along the span of the airfoil. This suggests that after the roughness elements reach a certain size, a physical mechanism or a combination of physical mechanisms is causing some heat enhancement that triggers the roughness elements beyond a given distance from the attachment line to grow into small feathers to a height at which the flow field and the heat transfer 
on the element protruding into the flow keep the feather growing in height and with a preferred direction. It is not known if the mechanism or mechanisms initiate the growth in the preferred direction or if they only trigger the roughness elements to grow into glaze ice feathers. The unknown physical mechanisms appear to act only in the beginning of the ice accretion process, depend on tunnel conditions, and show a very strong dependence on the sweep angle.

Measurements of the dependence of the critical distance $d_{c r}$ on velocity and sweep angle are needed to gain understanding of the physical mechanisms that determine it, and to determine the kind of ice accretion that will form on an airfoil at a given set of tunnel conditions.

\section{Consistency Between the Results Obtained with the Old and New Spray System}

The present work on scallop formation was done after a new spray system was installed in the IRT. To check the consistency between the results obtained with the old and the new spray systems, nine measurements of the critical distance done with the old spray system, were repeated with the new system and compared.

Table 3 presents the measurements of the critical distance obtained when the old spray system was still installed in the tunnel. Table 4 presents the measurements of the critical distance with the new spray system installed in the tunnel. For $15^{\circ}$ and $30^{\circ}$ sweep angles measurements were carried out at velocities of 150,200 , and $250 \mathrm{mph}$ with other conditions the same as the base case. The values of the critical distance measured after the new spray system was installed, agree within 0.5 millimeter with the values of the critical distance that were measured when the old spray system was still in the tunnel. For a sweep angle of $45^{\circ}$, measurements were carried out at velocities of 100,150 , and $250 \mathrm{mph}$ with other conditions the same as the base case. With the new spray system for each case the ice accretion was found to be a complete scallop ( $d_{c r}=0$ millimeters), this is in agreement with the results obtained with the old spray system.

Figures 4 through 11 show the photographic data for four of the nine cases, with the data for the ice accretions obtained with the old and new spray system placed side by side.
The close agreement between the results of the two tests, one done in June 1996 with the old spray system, and the other done in October 1998 with the new spray system, shows the high degree of repeatability of the critical distance measurements. This allows the use and comparison of the results and conclusions obtained in the two separate tests.

\section{Effect of Sweep Angle for a Velocity of $75 \mathrm{mph}$}

For a velocity of $75 \mathrm{mph}$, icing runs were carried out at sweep angles from $0^{\circ}$ to $45^{\circ}$ at $5^{\circ}$ increments, for ice accretion times of 5 and 10 minutes. At each sweep angle photographic and casting data were obtained, and the critical distance, $d_{c r}$, was measured from them. On figure 12 the critical distance in millimeters is plotted against sweep angle in degrees. Measurements from the photographic data and the casting data are presented. Between $0^{\circ}$ and $25^{\circ}$ the critical distance decreases slowly from about 13 millimeters to about 10 millimeters. Between $25^{\circ}$ and $35^{\circ}$ the critical distance decreases rapidly and reaches a value of 0 millimeters (complete scallop case) at $35^{\circ}$, and it remains at 0 millimeters for sweep angles of $40^{\circ}$ and $45^{\circ}$.

For a sweep angle of $0^{\circ}$ (figure 13), the 2D case, the attachment line zone (we are keeping the nomenclature used for the swept wing cases although in the $2 \mathrm{D}$ there is no attachment line proper but a stagnation line) and the glaze ice feathers zone can be observed. The ice of the attachment line zone is covered with roughness elements and also shows a narrow cavity running along the stagnation line (this was observed only for the $0^{\circ}$ sweep angle). The glaze ice feathers zone is made of individual glaze ice feathers with a preferred direction of growth (figure 14) oriented parallel to the stagnation line. The feathers located at the end of the attachment line zone (beginning of glaze ice feathers zone) grow next to the ice of the attachment line zone and some are being covered by the ice. As the sweep angle is incremented to $5^{\circ}, 10^{\circ}, 15^{\circ}$, $20^{\circ}, 25^{\circ}$, and $30^{\circ}$ sweep angles, the extent of the attachment line zone decreases but overall the ice shape maintains a similarity to the ice shape for the $0^{\circ}$ case. Figure 15 shows the ice shape for the $30^{\circ}$ sweep angle case. The attachment line zone and the glaze ice feathers zone can be observed. The attachment line zone is covered with roughness elements. The glaze ice feathers zone is made of large individual feathers (figure 16) with a preferred 
direction of growth. The feathers at the beginning of the glaze ice feathers zone grow next to the attachment line zone ice, and the ice of the attachment line is covering the top of a few of the feathers. When the sweep angle is increased to $35^{\circ}$ the top part of large feathers can be observed along the attachment line area (figures 17 and 18) with the space between feathers filled with ice covered with roughness elements. Although only the top of these feathers can be observed, they look large compared to the feathers located away from the attachment line area. The feathers away from the attachment line area (figure 18) show a preferred direction of growth. Because of the presence of feathers along the attachment line, the value of the critical distance is now 0 millimeters, and the ice accretion is now considered a complete scallop. For $40^{\circ}$ sweep angle (figures 19 and 20) the area around the attachment line also shows the upper part of large feathers, with ice covered with roughness elements filling the space between the feathers and almost covering them. The ice accretion is also a complete scallop. The feathers away from the attachment line area (figure 20) are smaller in size compared to the ones along the attachment line and exhibit a preferred direction of growth. For $45^{\circ}$ (figure 21) the ice accretion also show large feathers along the attachment line but in this case a greater part of each feather along the attachment line can be observed. As in the $35^{\circ}$ and $40^{\circ}$ cases the feathers away from the attachment line are smaller and exhibit a preferred direction of growth.

The photographic data for 10 minutes allows observation of the changes in the angle that the preferred direction of growth of the feathers makes with respect to the attachment line direction as the sweep angle is increased. It also shows how those changes affect the formation of scallop tips on the ice shape. At sweep angles of $5^{\circ}$ and $10^{\circ}$ the preferred direction of growth of the feathers is still nearly parallel to the stagnation line direction (figure 22) and the ice shape is similar to the $0^{\circ}$ case. At a $15^{\circ}$ sweep angle, the preferred direction of growth of the feathers is beginning to show a very small angle with respect to the attachment line direction (figure 23). At $20^{\circ}$ sweep angle, the preferred direction of growth of the feathers shows a small but measurable angle with respect to the attachment line direction (figure 24), and the feathers are beginning to form scallop tips. At $30^{\circ}$ the angle that the preferred direction of growth makes with respect to the attachment line is large enough for the feathers to form scallop tips (figure 25). Summarizing, at $0^{\circ}, 5^{\circ}, 10^{\circ}$, and $15^{\circ}$ sweep angles, the resulting ice shapes can be considered as noscallops. At $20^{\circ}, 25^{\circ}$, and $30^{\circ}$ sweep angles the resulting ice shapes are incomplete scallops. At $35^{\circ}, 40^{\circ}$ and $45^{\circ}$ sweep angles the ice shapes are complete scallops.

\section{Effect of Sweep angle for a Velocity of $100 \mathrm{mph}$}

For a velocity of $100 \mathrm{mph}$, icing runs were carried out at sweep angles from $0^{\circ}$ to $45^{\circ}$ at $5^{\circ}$ increments, for ice accretion times of 5 and 10 minutes. Photographic and casting data were obtained and values of the critical distance, $d_{c r}$, were measured from them. On figure 26 the critical distance in millimeters is plotted against sweep angle in degrees. Measurements from the photographic data and the casting data are presented. Between $0^{\circ}$ and $25^{\circ}$ the critical distance decreases slowly from about 13 millimeters to about 9 millimeters. Between $25^{\circ}$ and $35^{\circ}$ the critical distance decreases rapidly and reaches a value of 0 millimeters (complete scallop case) at $35^{\circ}$, and it remains at 0 millimeters for sweep angles of $40^{\circ}$ and $45^{\circ}$.

Although qualitatively the ice accretions for 75 and $100 \mathrm{mph}$ are similar, there are quantitative differences between the ice shapes. Ice accretions at $100 \mathrm{mph}$ are thicker along the attachment line than the ones at $75 \mathrm{mph}$. This is reflected in the height of the ice (measurement taken directly on the ice accretion) at the attachment line location. For 75 $\mathrm{mph}$ the height of the ice accretions ranges from 3.0 to 4.1 millimeters. For $100 \mathrm{mph}$ the thickness ranges from 4.1 to 5.8 millimeters.

At $0^{\circ}$ sweep angle (figure 27), the $2 \mathrm{D}$ case, the attachment line zone and the glaze ice feathers zone can be observed. The ice of the attachment line is covered with roughness elements, and the narrow cavity along the stagnation line can be seen. Individual feathers showing a preferred direction of growth can be observed in the glaze ice feathers zone (figure 28). The preferred direction of growth is aligned with the stagnation line. The ice of the attachment line zone is forming most of the ice accretion. All these characteristics are similar to the ones observed at $75 \mathrm{mph}$ and $0^{\circ}$ sweep angle. Figure 29 shows the ice accretion at $25^{\circ}$ sweep angle. As was the case for $75 \mathrm{mph}$, the extent of the attachment line zone has decreased, and the glaze ice feathers zone is made of mostly individual feathers showing a preferred direction of growth 
(figure 30). Similar to what was observed for 75 $\mathrm{mph}$ at sweep angles of $35^{\circ}, 40^{\circ}$, and $45^{\circ}$, the ice accretion shows a major difference compared to the ice accretions for lower sweep angles. Along the attachment line, large feathers appear (figures 31,32 and 33). Only part of the top of the feathers can be observed, and the space between the feathers is filled with ice. Since feathers appear along the attachment line area the critical distance is zero, and the ice shape for those sweep angles is considered a complete scallop.

At an ice accretion time of 10 minutes the ice shapes are more developed and the interaction between the attachment line ice and the feathers can be observed more clearly. In addition, the development of scallop tips as the sweep angle is increased can be seen. At $5^{\circ}, 10^{\circ}$, and $15^{\circ}$ sweep angles, the ice of the attachment line is covering most of the feathers (figure 34) but not all of them (figure 35). Some of the feathers that are not covered form some degree of scallop tips. At $20^{\circ}, 25^{\circ}$, and $30^{\circ}$ sweep angles the number of feathers not covered by the ice of the attachment line that are forming scallop tips increases and the ice accretions for those sweep angles can be considered as incomplete scallops (figure 36). Summarizing, at $0^{\circ}, 5^{\circ}, 10^{\circ}$, and $15^{\circ}$ sweep angles, the resulting ice shapes can be considered as no-scallops. At $20^{\circ}$, $25^{\circ}$ and $30^{\circ}$ sweep angles, the resulting ice shapes are incomplete scallops. At $35^{\circ}, 40^{\circ}$, and $45^{\circ}$ sweep angles the ice shapes are complete scallops.

\section{Effect of Sweep angle for a Velocity of $150 \mathrm{mph}$}

For a velocity of $150 \mathrm{mph}$, icing runs were carried out at sweep angles from $0^{\circ}$ to $45^{\circ}$ at $5^{\circ}$ increments. For each sweep angle casting data and photographic data were obtained and the critical distance was measured from them. On figure 37 the critical distance in millimeters is plotted against sweep angle in degrees. Measurements from the photographic data and the casting data are presented. Between $0^{\circ}$ and $25^{\circ}$ the critical distance decreases slowly from about 11.5 millimeters to about 10 millimeters. Between $25^{\circ}$ and $40^{\circ}$ the critical distance decreases rapidly and reaches a value of 0 millimeters (complete scallop case) at $40^{\circ}$, and it remains at 0 millimeters for a sweep angle of $45^{\circ}$.

Figure 38 compares the pencil tracings of the ice shapes for sweep angles of $0^{\circ}, 20^{\circ}$, and $40^{\circ}$, at velocities of 150 and $100 \mathrm{mph}$. The ice shapes at $150 \mathrm{mph}$ are different from the ones at $100 \mathrm{mph}$. The difference is in the actual form of the ice shapes and in their size. Ice shapes at $150 \mathrm{mph}$ are thicker along the attachment line. The height of the ice measured at the attachment line location ranges from 5.1 to 7.4 millimeters, which is larger that the observed ranges at the lower velocities.

For a sweep angle of $0^{\circ}$ (figure 39), the 2D case, the attachment line zone and the glaze ice feathers zone can be observed. The ice of the attachment line is covered with roughness elements and it is covering the feathers in the glaze ice feathers zone. This characteristic of the ice accretion is different from what was observed at velocities of 75 and $100 \mathrm{mph}$. At the lower velocities the ice of the attachment line zone is not covering the glaze ice feathers zone. On figure 39, the glaze ice feathers zone can be observed because of the transparency of the ice covering the feathers, but the separation between the two zones is barely visible. A side view of the ice accretion (figure 40) shows that the ice of the attachment line zone has covered the top of the feathers, has spilled over them and is covering most of their sides. Because the sweep angle is $0^{\circ}$, the preferred direction of growth of the feathers (which is normal to the streamline direction) is oriented parallel to the stagnation line direction. The physical mechanisms of scallop tip formation cannot operate, no scallop tips are formed, and the resulting ice shape is a no-scallop. At a sweep angle of $5^{\circ}$ the ice accretion is similar to the $0^{\circ}$ case. At a sweep angle of $10^{\circ}$ the ice accretion is similar to the $0^{\circ}$ and $5^{\circ}$ cases but the feathers in the glaze ice feathers zone are beginning to form some degree of scallops tips (figure 41). At this sweep angle, the angle that the preferred direction of growth of the feathers makes with respect to the attachment line direction is still not large enough to allow the physical mechanisms of scallop tip formation to fully operate, or to prevent the ice of the attachment line zone from totally covering the feathers (figure 42). The resulting ice shape is a no-scallop. The same situation occurs at sweep angles of $15^{\circ}$ and $20^{\circ}$. At $25^{\circ}$ the angle that the preferred direction of growth of the feathers makes with respect to the attachment line direction is large enough to allow the mechanisms of formation of scallop tips to occur. The angle is also large enough so that the ice of the attachment line cannot totally cover the feathers. The resulting ice shape shows scallop tips and is an incomplete scallop (figures 43 and 44 ). At $30^{\circ}$ and $35^{\circ}$ sweep 
angles the ice shapes show a decrease in the extent of the attachment line zone (figure 45), and scallop tips that are better defined and developed than the ones formed at 75 and $100 \mathrm{mph}$. At $40^{\circ}$ sweep angle the critical distance is zero millimeters and the ice shape (figure 46) is a complete scallop. This is different from what was observed at 75 and $150 \mathrm{mph}$, at the lower speeds the critical distance decreases to 0 millimeters as the sweep angle reaches $35^{\circ}$. For $45^{\circ}$ sweep angle the ice shape is a complete scallop.

\section{Effect of Sweep angle for a Velocity of $200 \mathrm{mph}$}

For a velocity of $200 \mathrm{mph}$, icing runs were carried out at sweep angles from $0^{\circ}$ to $45^{\circ}$ at $5^{\circ}$ increments. For each sweep angle casting data and photographic data were obtained and the critical distance was measured from them. On figure 47 the critical distance in millimeters is plotted against sweep angle in degrees. Measurements from the photographic data and the casting data are presented. Between $0^{\circ}$ and $25^{\circ}$ the critical distance decreases slowly from about 10.5 millimeters to about 8 millimeters. Between $25^{\circ}$ and $40^{\circ}$ the critical distance decreases rapidly and reaches a value of 0 millimeters (complete scallop case) at $40^{\circ}$, and it remains at 0 millimeters for a sweep angle of $45^{\circ}$.

For $200 \mathrm{mph}$ the ice shapes at each sweep angle are larger than the ones at $150 \mathrm{mph}$. The height of the ice accretions measured at the attachment line ranges from 6.1 to 13.7 millimeters.

Although there are quantitative differences between the ice shapes at 200 and $150 \mathrm{mph}$, qualitatively the ice shapes are similar. At a sweep angle of $0^{\circ}$ (figure 48), the 2D case, the ice of the attachment line zone is covering the feathers in the glaze ice feathers zone. The transparency of the ice of the attachment line zone covering the feathers allows viewing of the glaze ice feathers zone. All the ice of the attachment line zone (including the one covering the glaze ice feathers zone) is covered with roughness elements. As in the other velocity cases for $0^{\circ}$ sweep angle, a narrow cavity can be seen along the stagnation line. A side view of the ice accretion (figure 49) shows that the ice of the attachment line zone has covered the top of the feathers, spills over and covers most of their sides. Because the feathers' preferred direction of growth is parallel to the stagnation line direction, the mechanisms of scallop tip formation cannot operate, and the feathers form a glaze ice feathers zone but no scallop tips. The resulting ice shape is a no-scallop. These characteristics of the ice shape were also observed at $150 \mathrm{mph}$. As the sweep angle is increased to $5^{\circ}, 10^{\circ}, 15^{\circ}, 20^{\circ}$ and $25^{\circ}$, the attachment line zone and the glaze ice feathers are present (figure 50), and the ice of the attachment line zone is covering the glaze ice feathers zone. The angle that the preferred direction of growth of the feathers in the glaze ice feathers zone makes with respect to the attachment line direction increases as the sweep angle is increased from $5^{\circ}$ to $25^{\circ}$, but it is not large enough for the physical mechanisms of scallop formation to develop well defined scallop tips, and the angles are not large enough to prevent the feathers from being totally covered by the ice of the attachment line zone (figures 51). The ice accretion is a noscallop. As was the case for a velocity of $150 \mathrm{mph}$, at $200 \mathrm{mph}$ for $30^{\circ}$ and $35^{\circ}$ sweep angles (figure 52) the extent of the attachment line zone decreases and the ice accretion shows well defined scallop tips. When the sweep angle is increased to $40^{\circ}$ the ice accretion becomes a complete scallop (figure 53). At $45^{\circ}$ sweep angle the ice accretion remains a complete scallop (figure 54).

\section{Velocity Effect at a Given Sweep Angle}

On figure 55, the values of the critical distance (measured from the photographic data) for velocities of $75,100,150$, and $200 \mathrm{mph}$ are plotted against sweep angle in degrees, for sweep angles from $0^{\circ}$ to $45^{\circ}$ at $5^{\circ}$ increments. Between $0^{\circ}$ and $25^{\circ}$ sweep angles the general trend in the data is for the critical distance to be smaller at $200 \mathrm{mph}$ and larger at $75 \mathrm{mph}$ at a given sweep angle. The trend is not followed at sweep angles larger than $25^{\circ}$. Between $30^{\circ}$ and $35^{\circ}$ sweep angle, the value of the critical distance for $75 \mathrm{mph}$ and $100 \mathrm{mph}$ is decreasing faster than for 150 and $200 \mathrm{mph}$. At $35^{\circ}$ sweep angle the critical distance for 75 and $100 \mathrm{mph}$ has decreased to zero while the critical distances for 150 and $200 \mathrm{mph}$ are 7 and 5.5 millimeters respectively. At $40^{\circ}$ and $45^{\circ}$ sweep angles the critical distance is zero for all the velocities.

\section{Angle of the Feathers at each Sweep Angle for $150 \mathrm{mph}$}

When the glaze ice feathers zone and the attachment line zone are present, the angle that the preferred direction of growth of the feathers makes with respect to the attachment line determines the type of ice accretion. For the formation of 
incomplete scallops, a minimum angle is needed for the mechanisms of scallop tip formation to operate and for the feathers (and incipient scallop tips) to not be totally covered by the ice of the attachment line. Otherwise, the ice accretion will be a no-scallop. The prediction of the angle for feathers located at a given distance from the attachment line, is based on the experimental observation ${ }^{8}$ that the preferred direction of growth of the feathers is perpendicular to the external streamline direction. On figure 56, for a NACA 0012 airfoil geometry, the angle (in degrees) that a straight line normal to the streamlines makes with the attachment line direction is plotted versus distance from the attachment line (in millimeters), for sweep angles from $0^{\circ}$ to $45^{\circ}$ at $5^{\circ}$ increments. The shape of the streamlines depends only on the geometry of the airfoil and the sweep angle, not on the free stream velocity. Therefore, figure 56 is valid for any of the velocities. Since the preferred direction of growth of the feathers is in a direction normal to the streamlines, figure 56 can be interpreted as a plot of the angle that the preferred direction of growth of the feathers makes with respect to the attachment line direction, versus the distance from the attachment line where the feathers are located. An approximate value of this angle can be calculated from the knowledge of the sweep angle, the critical distance, and the extent of the glaze ice feathers zone. In general it is difficult to measure accurately the angle of the feathers from the photographic data because the angle of view at which the picture is taken distorts the measurement. For the $150 \mathrm{mph}$ base case at a $25^{\circ}$ sweep angle when the angle of the feathers is large enough to form scallop tips, the angle of the preferred direction of growth of the feathers was measured at approximately $30^{\circ}$ from the photographic data. Figure 56 together with the measured critical distance for this run predicts an angle of $25^{\circ}$ for the preferred direction of growth of the feathers.

\section{Observations on the End Cap of the Airfoil}

At each velocity and sweep angle, photographic data were taken on the end cap of the airfoil. The observations on the end cap show the effect of changing the local sweep angle at a given set of tunnel conditions, and the formation of scallops at sweep angles larger than $45^{\circ}$. In addition, since the leading edge radius for the end cap decreases as the sweep angle increases along the end cap, it allows observation of the characteristics of nearly individual scallops. The effect of the increase in the velocity component along the attachment line on the growth of the feathers can also be studied. On figure 57, the effect of the local sweep angle on the critical distance can be observed. As the local sweep angle increases, the critical distance rapidly decreases and the ice accretion becomes covered with glaze ice feathers. Figure 58 shows the formation of scallops on the end cap up to a local sweep angle of $72.5^{\circ}$. On figure 59 a single scallop near the end of the end cap is shown. The inclination of the scallop into the flow can be seen. At the base of the scallop, the growth of the scallop from a roughness element can be observed.

\section{Summary and Conclusions}

An experiment was conducted to understand the effect of sweep angle and velocity on the critical distance. Icing runs were conducted with a NACA 0012 swept wing tip at sweep angles from $0^{\circ}$ to $45^{\circ}$ at $5^{\circ}$ increments, for velocities of $75,100,150$, and $250 \mathrm{mph}$. Tunnel temperature of $25^{\circ} \mathrm{F}, 0.75 \mathrm{~g} / \mathrm{m}^{3}$ LWC and $20 \mu \mathrm{m}$ MVD were maintained for all runs. Ice shape tracings, photographic data, and casting data were obtained and from them values of the critical distance were measured. In addition, a grid was painted on the end cap of the airfoil to indicate the change of the local sweep angle and photographic data were obtained.

The experimental investigation showed that for the 75 and $100 \mathrm{mph}$ cases, between $0^{\circ}$ and $25^{\circ}$ sweep angles, the critical distance decreases very slowly, and when the sweep angle reaches $25^{\circ}$ the critical distance starts to decrease rapidly and reaches a value of 0 millimeters (complete scallop case) at $35^{\circ}$ sweep angle. Photographic data of the ice accretion shows that at $0^{\circ}$ the attachment line zone forms most of the ice shape, while the glaze ice feathers zone is made of large individual feathers not covered by the ice of the attachment line zone and exhibiting a preferred direction of growth parallel to the attachment line direction. The ice of the attachment line was covered with roughness elements. Large and small elements mixed together were observed. As the sweep angle was increased the extent of the attachment line zone slowly decreased. The angle of the preferred direction of growth of the feathers in the glaze ice feathers zone with respect to the attachment line increased and the larger feathers started giving the ice shape some degree of scallop tips. Despite the change in the extent of the attachment line zone and the angle of the feathers (that can be explained by the 
tendency of the preferred direction of growth to be oriented perpendicular to the external streamlines), the ice shapes at sweep angles between $5^{\circ}$ and $25^{\circ}$ resemble the $0^{\circ}$ sweep angle case. The ice shapes suggest that the same physical mechanisms that form the ice shape at $0^{\circ}$ are forming the ice shapes up to $25^{\circ}$ sweep angle. Between $25^{\circ}$ and $30^{\circ}$ sweep angles the extent of the attachment line zone decreases rapidly, and at $35^{\circ}$ sweep angle there is a dramatic change in the ice shape as large feathers appear along the attachment line zone. These feathers are larger than the feathers in the glaze ice feathers zone and only the tops of the feathers can be observed.

For $150 \mathrm{mph}$ the critical distance decreases slowly between $0^{\circ}$ and $25^{\circ}$. Between $25^{\circ}$ and $40^{\circ}$ sweep angles the critical distance decreases rapidly reaching a value of 0 millimeters (complete scallop) at $40^{\circ}$. The photographic data shows that at $0^{\circ}$ sweep angle the ice of the attachment line zone is totally covering the feathers in the glaze ice feathers zone. As the sweep angle is increased between $5^{\circ}$ and $20^{\circ}$, the angle that the preferred direction of growth of the feathers makes with respect to the attachment line direction increases but is not enough to form incomplete scallops. Aside from the change in the angle of the preferred direction of growth of the feathers, the ice shape is basically similar to the $0^{\circ}$ sweep angle case. As the sweep angle is increased to $25^{\circ}$, the angle of the preferred direction of growth of the feathers is large enough to form incomplete scallops. At $30^{\circ}$ and $35^{\circ}$ the ice shape shows more defined scallop tips and a decrease in the extent of the attachment line. At $40^{\circ}$ the ice shape is a complete scallop. When the experiment was carried out for $200 \mathrm{mph}$ the behavior of the critical distance and the ice shape was similar.

The change in the critical distance with the sweep angle, and the observation of the corresponding ice accretions, indicate that the basic mechanism that is triggering the growth of the roughness elements into feathers seems to operate up to about $25^{\circ}$ sweep angle. At this sweep angle there is noticeable change indicated by the rapid decrease of the critical distance. Either the mechanism operating before is enhanced or a new mechanism comes into play and this leads to the triggering into feathers of the roughness elements closer and closer to the attachment line.
In previous investigations ${ }^{7,8}$ it was suggested that the strong dependence of scallop formation on sweep angle pointed towards the need to consider boundary layer instabilities as one of the physical mechanisms operating in the formation of scallops. The boundary layer instability mechanism that was proposed was the cross flow instability. The results of the present investigation show that at $25^{\circ}$ sweep angle, either there is a enhancement of the physical mechanisms operating in the previous sweep angles, or a new mechanism or mechanisms start to come into play. This is specially seen in the rapid decrease in the extent of the attachment line zone and the eventual formation of complete scallops. The cross flow instability starts to be a factor in the transition of the boundary layer when the sweep angle of an airfoil is larger than about $25^{\circ}$. This seems to agree with the sweep angle at which the critical distance starts to decrease rapidly. The observed change in $d_{c r}$ is consistent with recent calculations of stationary cross flow instability for a NACA 0012 airfoil $^{9}$; providing good circumstantial support for the cross flow hypotheses.

In addition to the investigations on the effect of sweep angle and velocity, photographic data were obtained on the ice accretions formed on the end cap of the airfoil. The data confirm the strong dependence of the critical distance on sweep angle and also show that for velocities of $75 \mathrm{mph}$ to 200 mph complete scallops are formed all along the end cap up to a local sweep angle of $72.5^{\circ}$.

The results of the present experimental investigation confirmed that the critical distance is the important parameter in the formation of ice accretions on swept wings at glaze ice conditions. The measured dependence of the critical distance on sweep angle at a given velocity, and the ice accretions formed, should help in identifying the physical mechanisms that determine it. Additional research on roughness effects, attachment line ice growth, and glaze ice feathers growth, followed by flow field and heat transfer studies, are needed to identify and gain understanding on the physical mechanisms involved. In order to predict ice accretions on swept wings, an understanding of those physical mechanisms and a prediction of the critical distance will be needed. 


\section{Acknowledgements}

The authors would like to thank Mr. William Sexton, Mr. Dave Sheldon and all the personnel at the Icing Research Tunnel for their help in all phases of the experiment; Mrs. Tammy Langhals for her help with ice shape tracings; and the personnel of the Imaging Technology Center for their assistance with the photographic work.

\section{References}

1 Wilder, R.W., "A Theoretical and Experimental Means to Predict Ice Accretion Shapes for Evaluating Aircraft Handling and Performance Characteristics", AGARD Report No. 127 (Aircraft lcing), Ottawa, Canada, 1977.

${ }^{2}$ Pierre, M. and Vaucheret, X., "Icing Test Facilities and Test Techniques in Europe", AGARD Report No. 127 (Aircraft Icing), Ottawa, Canada, 1977.

${ }^{3}$ Laschka, B. and Jesse, R.E., "Ice Accretion and its Effects on Aerodynamics of Unprotected Aircraft Components", AGARD Report No. 127 (Aircraft lcing), Ottawa, Canada, 1977.
${ }^{4}$ Reehorst, A.L., "Prediction of Ice Accretion on a Swept NACA 0012 Airfoil and Comparisons to Flight Test Results", AIAA Paper 92-0043, Jan. 1992.

${ }^{5}$ Reehorst, A.L. and Bidwell, C., NASA Lewis Research Center internal document, 1991.

${ }^{6}$ Hedde, T. and Guffond, D., "Improvement of the ONERA 3D Icing Code, Comparison with 3D Experimental Shapes", AIAA Paper 93-0169, Jan. 1993.

7 Vargas, M. and Reshotko, E., "Physical Mechanisms of Glaze Ice Scallop Formations on Swept Wings", AlAA Paper 98-0491, Jan. 1998. NASA TM-1998-206616.

${ }^{8}$ Vargas, M., "Ice Accretion on Swept Wings at Glaze Ice Conditions", Ph.D. Thesis, Case Western Reserve University, Cleveland, Ohio, May 1998.

${ }^{9}$ Reshotko, E., Vargas, M. and Reed, H. L., "Ice Formation on Sweep Wings - Relation to Cross Flow Instability?", Bull. APS, Vol. 43 No. 9, Nov. 1998, p. 1993. 


\begin{tabular}{|c|c|c|c|c|c|c|}
\hline Run Number & Sweep Angle & $\begin{array}{c}\text { Velocity } \\
\text { (mph) }\end{array}$ & $\begin{array}{c}\text { Temperature } \\
\left({ }^{\circ} \mathrm{F}\right)\end{array}$ & $\begin{array}{l}\text { LWC } \\
\left(\mathrm{g} / \mathrm{m}^{3}\right)\end{array}$ & $\begin{array}{l}\text { MVD } \\
(\mu \mathrm{m})\end{array}$ & $\begin{array}{l}\text { Ice Accretion } \\
\text { Time } \\
\text { (min) }\end{array}$ \\
\hline O33098.03 & $0^{\circ}$ & 150 & 25 & 0.75 & 20 & 5 \\
\hline O42998.01 & $0^{\circ}$ & 150 & 25 & 0.75 & 20 & 5 \\
\hline O42998.02 & $5^{\circ}$ & 150 & 25 & 0.75 & 20 & 5 \\
\hline O42998.03 & $10^{\circ}$ & 150 & 25 & 0.75 & 20 & 5 \\
\hline O42998.04 & $15^{\circ}$ & 150 & 25 & 0.75 & 20 & 5 \\
\hline O42998.05 & $20^{\circ}$ & 150 & 25 & 0.75 & 20 & 5 \\
\hline O42998.06 & $25^{\circ}$ & 150 & 25 & 0.75 & 20 & 5 \\
\hline O42998.07 & $30^{\circ}$ & 150 & 25 & 0.75 & 20 & 5 \\
\hline O42998.08 & $35^{\circ}$ & 150 & 25 & 0.75 & 20 & 5 \\
\hline O42998.09 & $40^{\circ}$ & 150 & 25 & 0.75 & 20 & 5 \\
\hline O42998.10 & $45^{\circ}$ & 150 & 25 & 0.75 & 20 & 5 \\
\hline O42998.11 & $0^{\circ}$ & 200 & 25 & 0.75 & 20 & 5 \\
\hline O42998.12 & $5^{\circ}$ & 200 & 25 & 0.75 & 20 & 5 \\
\hline O43098.01 & $10^{\circ}$ & 200 & 25 & 0.75 & 20 & 5 \\
\hline O43098.02 & $15^{\circ}$ & 200 & 25 & 0.75 & 20 & 5 \\
\hline O43098.03 & $20^{\circ}$ & 200 & 25 & 0.75 & 20 & 5 \\
\hline O43098.04 & $25^{\circ}$ & 200 & 25 & 0.75 & 20 & 5 \\
\hline O43098.05 & $30^{\circ}$ & 200 & 25 & 0.75 & 20 & 5 \\
\hline O43098.06 & $35^{\circ}$ & 200 & 25 & 0.75 & 20 & 5 \\
\hline O43098.07 & $40^{\circ}$ & 200 & 25 & 0.75 & 20 & 5 \\
\hline O43098.08 & $45^{\circ}$ & 200 & 25 & 0.75 & 20 & 5 \\
\hline O43098.09 & $0^{\circ}$ & 100 & 25 & 0.75 & 20 & 5 \\
\hline O43098.10 & $5^{\circ}$ & 100 & 25 & 0.75 & 20 & 5 \\
\hline O43098.11 & $5^{\circ *}$ & 100 & 25 & 0.75 & 20 & 10 \\
\hline O43098.12 & $10^{\circ}$ & 100 & 25 & 0.75 & 20 & 5 \\
\hline O43098.13 & $15^{\circ}$ & 100 & 25 & 0.75 & 20 & 5 \\
\hline O50198.01 & $20^{\circ}$ & 100 & 25 & 0.75 & 20 & 5 \\
\hline O50198.02 & $25^{\circ}$ & 100 & 25 & 0.75 & 20 & 5 \\
\hline O50198.03 & $30^{\circ}$ & 100 & 25 & 0.75 & 20 & 5 \\
\hline O50198.04 & $35^{\circ}$ & 100 & 25 & 0.75 & 20 & 5 \\
\hline O50198.05 & $40^{\circ}$ & 100 & 25 & 0.75 & 20 & 5 \\
\hline O50198.06 & $45^{\circ}$ & 100 & 25 & 0.75 & 20 & 5 \\
\hline O50198.07 & $0^{\circ}$ & 75 & 25 & $0.75(0.80)$ & 20 & 5 \\
\hline O50198.08 & $5^{\circ}$ & 75 & 25 & $0.75(0.80)$ & 20 & 5 \\
\hline O50198.09 & $10^{\circ}$ & 75 & 25 & $0.75(0.80)$ & 20 & 5 \\
\hline O50198.10 & $15^{\circ}$ & 75 & 25 & $0.75(0.80)$ & 20 & 5 \\
\hline O50198.11 & $20^{\circ}$ & 75 & 25 & $0.75(0.80)$ & 20 & 5 \\
\hline O50198.12 & $25^{\circ}$ & 75 & 25 & $0.75(0.80)$ & 20 & 5 \\
\hline O50198.13 & $30^{\circ}$ & 75 & 25 & $0.75(0.80)$ & 20 & 5 \\
\hline O50198.14 & $35^{\circ}$ & 75 & 25 & $0.75(0.80)$ & 20 & 5 \\
\hline O50198.15 & $40^{\circ}$ & 75 & 25 & $0.75(0.80)$ & 20 & 5 \\
\hline O50198.16 & $45^{\circ}$ & 75 & 25 & $0.75(0.80)$ & 20 & 5 \\
\hline 101498.01 & $15^{\circ}$ & 75 & 25 & $0.75(0.80)$ & 20 & 5 \\
\hline 101498.02 & $25^{\circ}$ & 75 & 25 & $0.75(0.80)$ & 20 & 5 \\
\hline 101498.03 & $30^{\circ}$ & 75 & 25 & $0.75(0.80)$ & 20 & 5 \\
\hline 101498.04 & $35^{\circ}$ & 75 & 25 & $0.75(0.80)$ & 20 & 5 \\
\hline 101498.05 & $40^{\circ}$ & 75 & 25 & $0.75(0.80)$ & 20 & 5 \\
\hline 101498.06 & $45^{\circ}$ & 75 & 25 & $0.75(0.80)$ & 20 & 5 \\
\hline 101498.07 & $25^{\circ}$ & 100 & 25 & 0.75 & 20 & 5 \\
\hline 101498.08 & $30^{\circ}$ & 100 & 25 & 0.75 & 20 & 5 \\
\hline 101498.09 & $35^{\circ}$ & 100 & 25 & 0.75 & 20 & 5 \\
\hline 101498.10 & $30^{\circ}$ & 150 & 25 & 0.75 & 20 & 5 \\
\hline 101498.11 & $35^{\circ}$ & 150 & 25 & 0.75 & 20 & 5 \\
\hline 101498.12 & $40^{\circ}$ & 150 & 25 & 0.75 & 20 & 5 \\
\hline 101598.01 & $30^{\circ}$ & 200 & 25 & 0.75 & 20 & 5 \\
\hline 101598.02 & $35^{\circ}$ & 200 & 25 & 0.75 & 20 & 5 \\
\hline 101598.03 & $20^{\circ}$ & 75 & 25 & $0.75(0.80)$ & 20 & 5 \\
\hline 101598.04 & $5^{\circ}$ & 100 & 25 & 0.75 & 20 & 5 \\
\hline 101598.05 & $10^{\circ}$ & 100 & 25 & 0.75 & 20 & 5 \\
\hline 101598.06 & $15^{\circ}$ & 100 & 25 & 0.75 & 20 & 5 \\
\hline 101598.07 & $20^{\circ}$ & 100 & 25 & 0.75 & 20 & 5 \\
\hline 101598.08 & $5^{\circ}$ & 150 & 25 & 0.75 & 20 & 5 \\
\hline 101598.09 & $10^{\circ}$ & 150 & 25 & 0.75 & 20 & 5 \\
\hline 101598.10 & $15^{\circ}$ & 150 & 25 & 0.75 & 20 & 5 \\
\hline 101598.11 & $20^{\circ}$ & 150 & 25 & 0.75 & 20 & 5 \\
\hline 101598.12 & $25^{\circ}$ & 150 & 25 & 0.75 & 20 & 5 \\
\hline 102098.12 & $5^{\circ}$ & 75 & 25 & $0.75(0.80)$ & 20 & 5 \\
\hline 102098.13 & $10^{\circ}$ & 75 & 25 & $0.75(0.80)$ & 20 & 5 \\
\hline
\end{tabular}

Table 1. Test Matrix for the icing runs at an ice accretion time of 5 minutes 


\begin{tabular}{|c|c|c|c|c|c|c|}
\hline Run Number & Sweep Angle & $\begin{array}{c}\text { Velocity } \\
\text { (mph) }\end{array}$ & $\begin{array}{c}\text { Temperature } \\
\left({ }^{\circ} \mathrm{F}\right)\end{array}$ & $\begin{array}{l}\text { LWC } \\
\left(\mathrm{g} / \mathrm{m}^{3}\right)\end{array}$ & $\begin{array}{l}\text { MVD } \\
(\mu \mathrm{m})\end{array}$ & $\begin{array}{c}\text { Ice Accretion } \\
\text { Time } \\
\text { (min) }\end{array}$ \\
\hline O33098.01 & $0^{\circ}$ & 150 & 25 & 0.75 & 20 & 10 \\
\hline O41398.01 & $0^{\circ}$ & 150 & 25 & 0.75 & 20 & 10 \\
\hline O41398.02 & $0^{\circ}$ & 75 & 25 & $0.75(0.80)$ & 20 & 10 \\
\hline O41398.03 & $0^{\circ}$ & 100 & 25 & 0.75 & 20 & 10 \\
\hline O41398.04 & $0^{\circ}$ & 125 & 25 & 0.75 & 20 & 10 \\
\hline O41398.05 & $0^{\circ}$ & 175 & 25 & 0.75 & 20 & 10 \\
\hline O41398.06 & $0^{\circ}$ & 200 & 25 & 0.75 & 20 & 10 \\
\hline O41398.07 & $0^{\circ}$ & 225 & 25 & 0.75 & 20 & 10 \\
\hline O41498.18 & $45^{\circ}$ & 150 & 25 & 0.75 & 20 & 10 minutes \\
\hline O41598.01 & $5^{\circ}$ & 150 & 25 & 0.75 & 20 & 10 \\
\hline O41598.02 & $10^{\circ}$ & 150 & 25 & 0.75 & 20 & 10 \\
\hline O41598.03 & $15^{\circ}$ & 150 & 25 & 0.75 & 20 & 10 \\
\hline O41598.04 & $20^{\circ}$ & 150 & 25 & 0.75 & 20 & 10 \\
\hline O41598.05 & $25^{\circ}$ & 150 & 25 & 0.75 & 20 & 10 \\
\hline O41598.06 & $30^{\circ}$ & 150 & 25 & 0.75 & 20 & 10 \\
\hline O41598.07 & $35^{\circ}$ & 150 & 25 & 0.75 & 20 & 10 \\
\hline O41598.08 & $40^{\circ}$ & 150 & 25 & 0.75 & 20 & 10 \\
\hline O41598.09 & $45^{\circ}$ & 150 & 25 & 0.75 & 20 & 10 \\
\hline O41698.01 & $5^{\circ}$ & 200 & 25 & 0.75 & 20 & 10 \\
\hline O41698.02 & $10^{\circ}$ & 200 & 25 & 0.75 & 20 & 10 \\
\hline O41698.03 & $15^{\circ}$ & 200 & 25 & 0.75 & 20 & 10 \\
\hline O41698.04 & $20^{\circ}$ & 200 & 25 & 0.75 & 20 & 10 \\
\hline O41698.05 & $25^{\circ}$ & 200 & 25 & 0.75 & 20 & 10 \\
\hline O41698.06 & $30^{\circ}$ & 200 & 25 & 0.75 & 20 & 10 \\
\hline O41698.07 & $35^{\circ}$ & 200 & 25 & 0.75 & 20 & 10 \\
\hline O41698.08 & $40^{\circ}$ & 200 & 25 & 0.75 & 20 & 10 \\
\hline O41698.09 & $45^{\circ}$ & 200 & 25 & 0.75 & 20 & 10 \\
\hline O41698.10 & $5^{\circ}$ & 100 & 25 & 0.75 & 20 & 10 \\
\hline O41798.01 & $10^{\circ}$ & 100 & 25 & 0.75 & 20 & 10 \\
\hline O41798.02 & $15^{\circ}$ & 100 & 25 & 0.75 & 20 & 10 \\
\hline O41798.03 & $20^{\circ}$ & 100 & 25 & 0.75 & 20 & 10 \\
\hline O41798.04 & $25^{\circ}$ & 100 & 25 & 0.75 & 20 & 10 \\
\hline O41798.05 & $30^{\circ}$ & 100 & 25 & 0.75 & 20 & 10 \\
\hline O41798.06 & $35^{\circ}$ & 100 & 25 & 0.75 & 20 & 10 \\
\hline O41798.07 & $40^{\circ}$ & 100 & 25 & 0.75 & 20 & 10 \\
\hline O41798.08 & $45^{\circ}$ & 100 & 25 & 0.75 & 20 & 10 \\
\hline O41798.09 & $45^{\circ}$ & 75 & 25 & $0.75(0.80)$ & 20 & 10 \\
\hline O41798.10 & $40^{\circ}$ & 75 & 25 & $0.75(0.80)$ & 20 & 10 \\
\hline O41798.11 & $35^{\circ}$ & 75 & 25 & $0.75(0.80)$ & 20 & 10 \\
\hline O41798.12 & $30^{\circ}$ & 75 & 25 & $0.75(0.80)$ & 20 & 10 \\
\hline O41798.13 & $25^{\circ}$ & 75 & 25 & $0.75(0.80)$ & 20 & 10 \\
\hline O41798.14 & $20^{\circ}$ & 75 & 25 & $0.75(0.80)$ & 20 & 10 \\
\hline O41798.15 & $15^{\circ}$ & 75 & 25 & $0.75(0.80)$ & 20 & 10 \\
\hline O41798.16 & $10^{\circ}$ & 75 & 25 & $0.75(0.80)$ & 20 & 10 \\
\hline O41798.17 & $5^{\circ}$ & 75 & 25 & $0.75(0.80)$ & 20 & 10 \\
\hline 101398.10 & $0^{\circ}$ & 75 & 25 & $0.75(0.80)$ & 20 & 10 \\
\hline
\end{tabular}

Table 2. Test Matrix for the icing runs at an ice accretion time of 10 minutes 


\begin{tabular}{|c|c|c|c|c|c|c|c|}
\hline Run Number & Sweep Angle & $\begin{array}{c}\text { Velocity } \\
(\mathrm{mph})\end{array}$ & $\begin{array}{c}\text { Temperature } \\
\left({ }^{\circ} \mathrm{F}\right)\end{array}$ & $\begin{array}{c}\text { LWC } \\
\left(\mathrm{g} / \mathrm{m}^{3}\right)\end{array}$ & $\begin{array}{c}\text { MVD } \\
(\mu \mathrm{m})\end{array}$ & $\begin{array}{c}\text { Ice Accretion } \\
\text { Time } \\
(\mathrm{min})\end{array}$ & $\begin{array}{c}\text { Critical Dis- } \\
\text { tance } \\
(\mathrm{mm})\end{array}$ \\
\hline O62096.05 & 15 & 150 & 25 & 0.75 & 20 & 2 & 10.1 \\
\hline O62196.05 & 15 & 200 & 25 & 0.75 & 20 & 10 & 6.8 \\
\hline O62196.06 & 15 & 250 & 25 & 0.75 & 20 & 10 & 4 \\
\hline O62096.01 & 30 & 150 & 25 & 0.75 & 20 & 2 & 6 \\
\hline O62196.01 & 30 & 200 & 25 & 0.75 & 20 & 10 & 2 \\
\hline O62196.02 & 30 & 250 & 25 & 0.75 & 20 & 10 & 0 \\
\hline O62196.03 & 45 & 100 & 25 & 0.75 & 20 & 10 & 0 \\
\hline O61896.04 & 45 & 150 & 25 & 0.75 & 20 & 2 & 0 \\
\hline O62196.04 & 45 & 250 & 25 & 0.75 & 20 & 10 & 0 \\
\hline
\end{tabular}

Table 3. Values of the critical distance measured when the old spray system was still installed in the IRT.

\begin{tabular}{|c|c|c|c|c|c|c|c|}
\hline Run Number & Sweep Angle & $\begin{array}{c}\text { Velocity } \\
(\mathrm{mph})\end{array}$ & $\begin{array}{c}\text { Temperature } \\
\left({ }^{\circ} \mathrm{F}\right)\end{array}$ & $\begin{array}{c}\text { LWC } \\
\left(\mathrm{g} / \mathrm{m}^{3}\right)\end{array}$ & $\begin{array}{c}\text { MVD } \\
(\mu \mathrm{m})\end{array}$ & $\begin{array}{c}\text { Ice Accretion } \\
\text { Time } \\
(\mathrm{min})\end{array}$ & $\begin{array}{c}\text { Critical Dis- } \\
\text { tance } \\
(\mathrm{mm})\end{array}$ \\
\hline 101398.01 & 15 & 150 & 25 & 0.75 & 20 & 2 & $9.8(11.0)$ \\
\hline 101398.02 & 15 & 200 & 25 & 0.75 & 20 & 10 & $6.5(6.5)$ \\
\hline 101398.03 & 15 & 250 & 25 & 0.75 & 20 & 10 & $4.5(4.5)$ \\
\hline 101398.04 & 30 & 150 & 25 & 0.75 & 20 & 2 & $6.4(6.5)$ \\
\hline 101398.05 & 30 & 200 & 25 & 0.75 & 20 & 10 & $2.5(2.5)$ \\
\hline 101398.06 & 30 & 250 & 25 & 0.75 & 20 & 10 & 0 \\
\hline 101398.07 & 45 & 100 & 25 & 0.75 & 20 & 10 & 0 \\
\hline 101398.08 & 45 & 150 & 25 & 0.75 & 20 & 2 & 0 \\
\hline 101398.09 & 45 & 250 & 25 & 0.75 & 20 & 10 & 0 \\
\hline
\end{tabular}

Table 4. Values of the critical distance measured after a new spray system was installed in the IRT. 


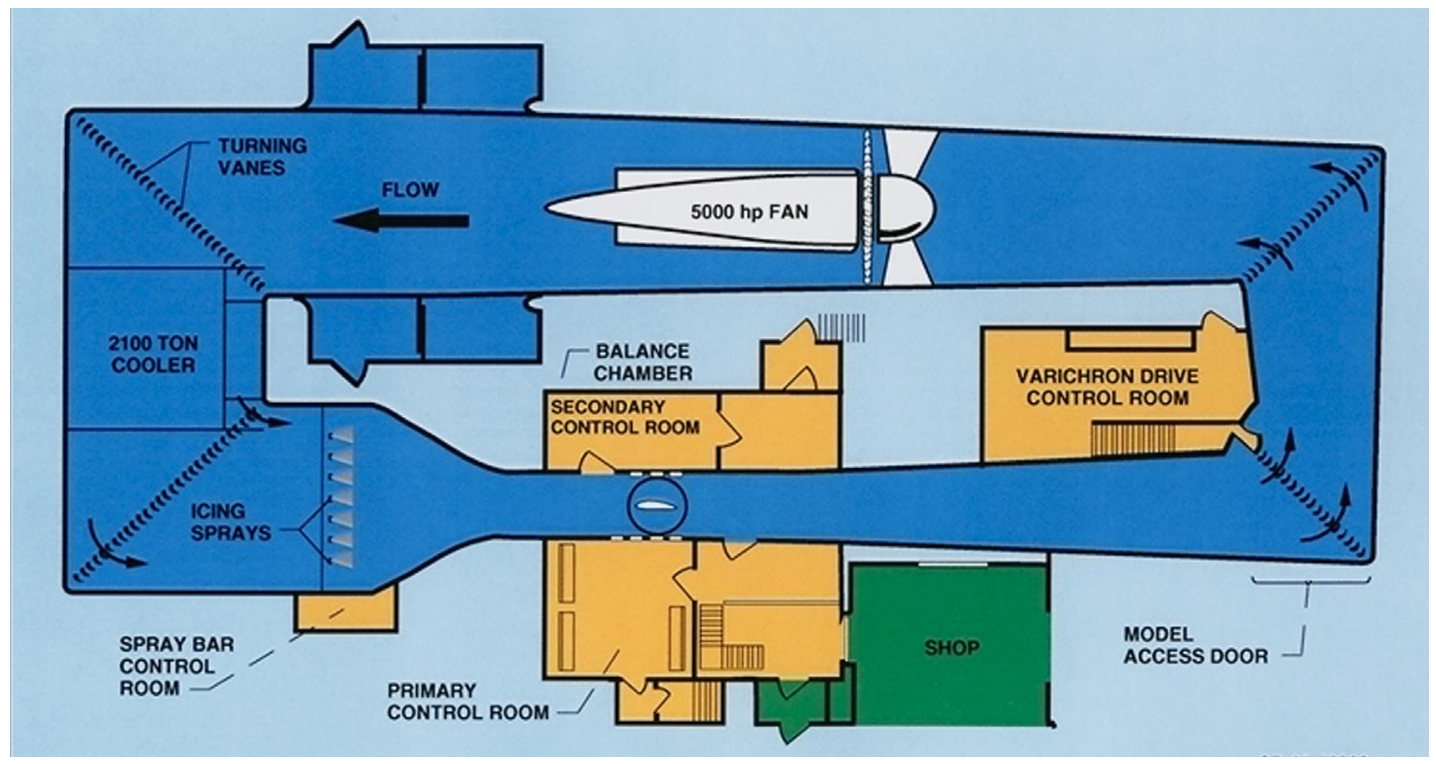

Figure 1. NASA Lewis Icing Research Tunnel, Plan view.

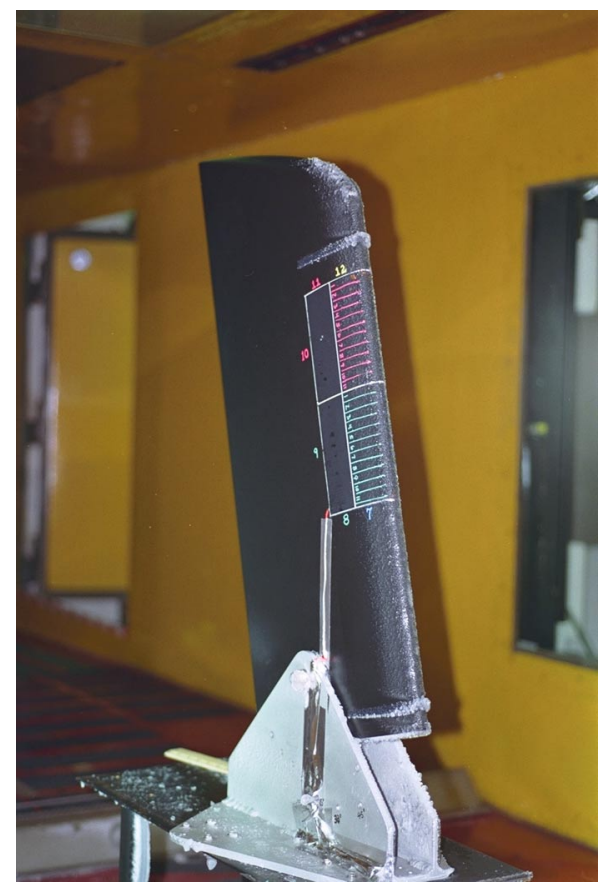

Figure 2. NACA 0012 swept wing tip in the IRT Test Section

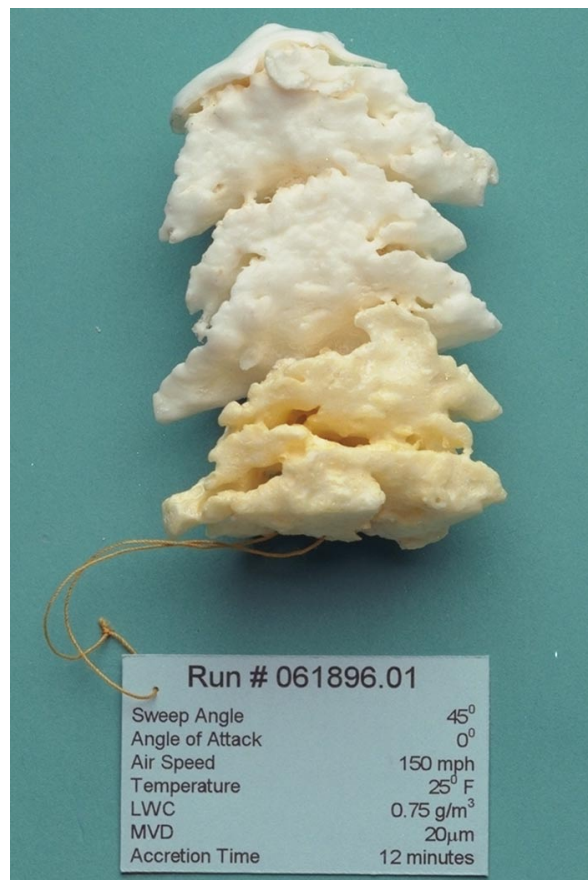

Figure 3. Urethane casting of an ice accretion. 


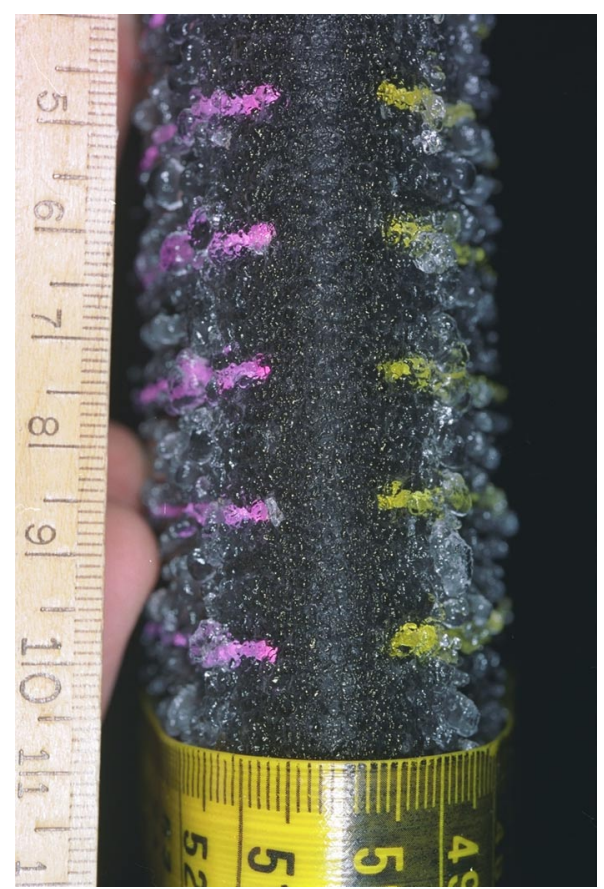

Figure 4. Front view of ice accretion at 2 minutes, showing the attachment line zone and the glaze ice feathers zone. Run conducted with 1998 spray system. $\Lambda=15^{\circ}, V=150 \mathrm{mph}$, $\mathrm{T}=25^{\circ} \mathrm{F}, \mathrm{LWC}=0.75 \mathrm{~g} / \mathrm{m}^{3}, \mathrm{MVD}=20 \mu \mathrm{m}, \tau=2 \mathrm{~min}$. Direction of flow is from bottom to top, scale of ruler is in centimeters, smallest division 1 millimeter

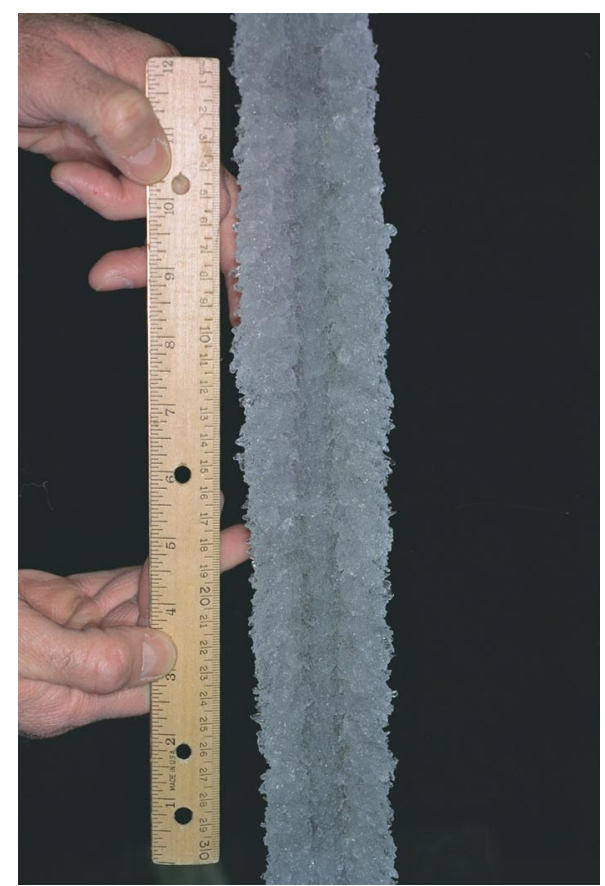

Figure 6. Front view of ice accretion. Run conducted with 1998 spray system. $\Lambda=15^{\circ}$, $\mathrm{V}=200 \quad \mathrm{mph}, \quad \mathrm{T}=25^{\circ} \mathrm{F}, \quad \mathrm{LWC}=0.75 \mathrm{~g} / \mathrm{m}^{3}$, $M V D=20 \mu \mathrm{m}, \tau=10 \mathrm{~min}$. Direction of flow is from bottom to top, scale of ruler is in centimeters and inches.

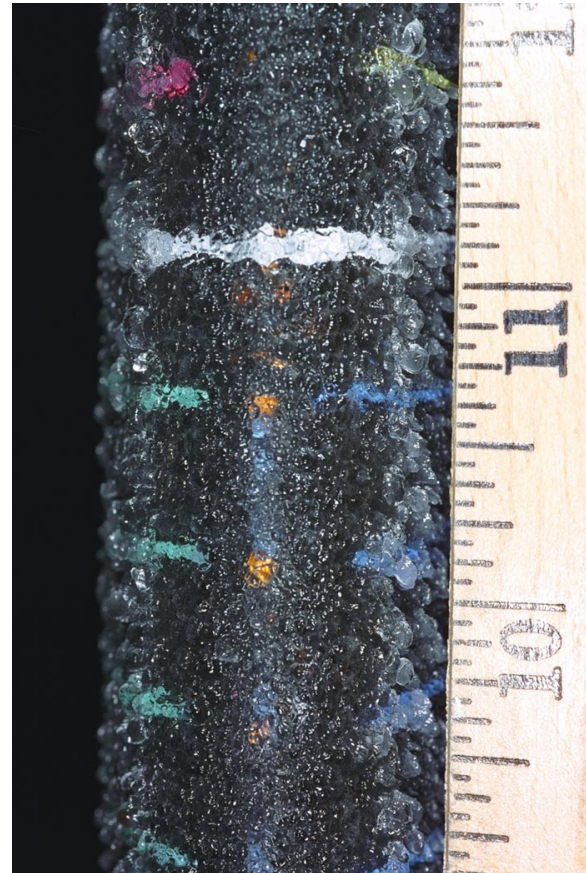

Figure 5. Front view of ice accretion at 2 minutes, showing the attachment line zone and the glaze ice feathers zone. Run conducted with 1996 spray system. $\Lambda=15^{\circ}, V=150 \mathrm{mph}$, $\mathrm{T}=25^{\circ} \mathrm{F}, \mathrm{LWC}=0.75 \mathrm{~g} / \mathrm{m}^{3}, \mathrm{MVD}=20 \mu \mathrm{m}, \tau=2 \mathrm{~min}$. Direction of flow is from bottom to top, scale of ruler is in inches.

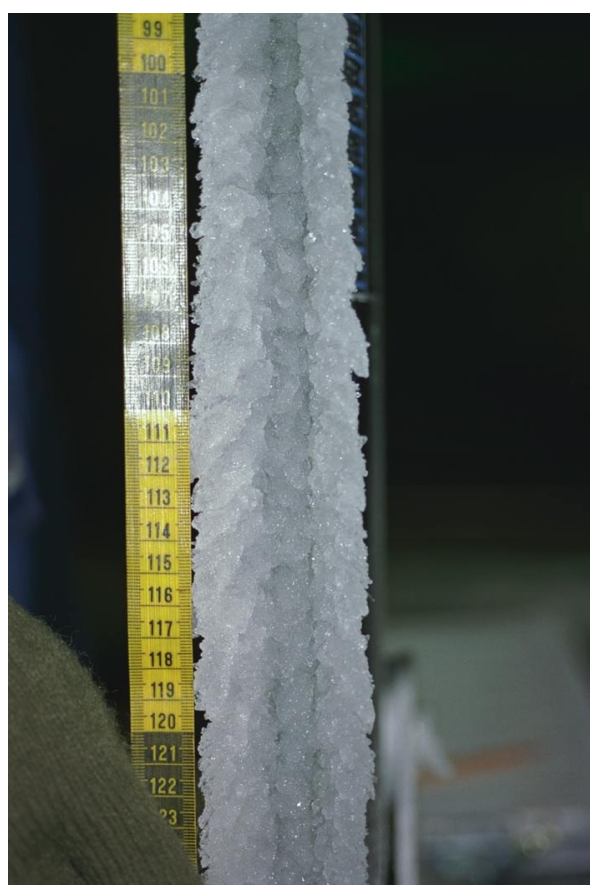

Figure 7. Front view of ice accretion. Run conducted with 1996 spray system. $\Lambda=15^{\circ}$, $\mathrm{V}=200 \mathrm{mph}, \quad \mathrm{T}=25^{\circ} \mathrm{F}, \quad \mathrm{LWC}=0.75 \mathrm{~g} / \mathrm{m}^{3}$, $M V D=20 \mu \mathrm{m}, \tau=10 \mathrm{~min}$. Direction of flow is from bottom to top, scale of ruler is in centimeters, smallest division 1 millimeter. 


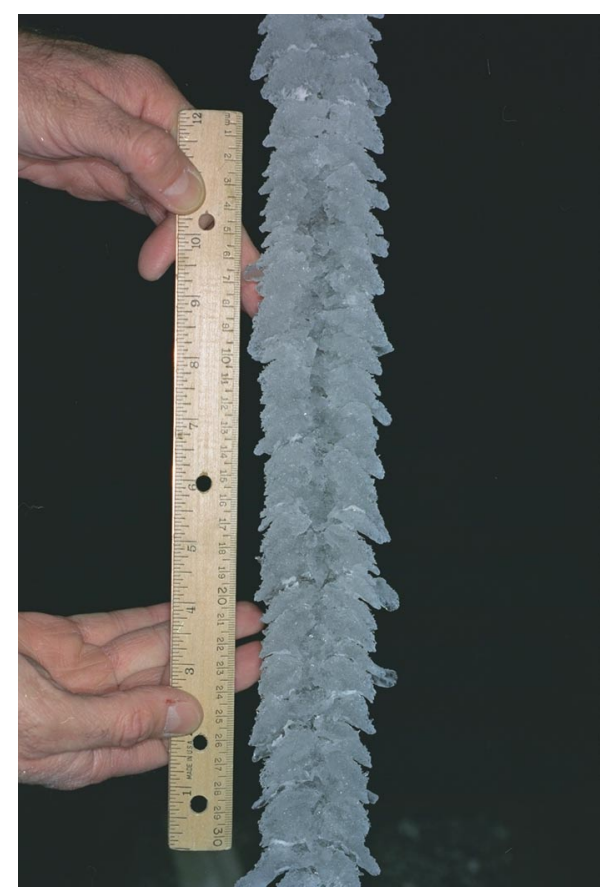

Figure 8. Front view of ice accretion. Run conducted with 1998 spray system. $\Lambda=30^{\circ}$, $\mathrm{V}=200 \quad \mathrm{mph}, \quad \mathrm{T}=25^{\circ} \mathrm{F}, \quad \mathrm{LWC}=0.75 \mathrm{~g} / \mathrm{m}^{3}$, $M V D=20 \mu \mathrm{m}, \tau=10 \mathrm{~min}$. Direction of flow is from bottom to top, scale of ruler is in centimeters and inches.

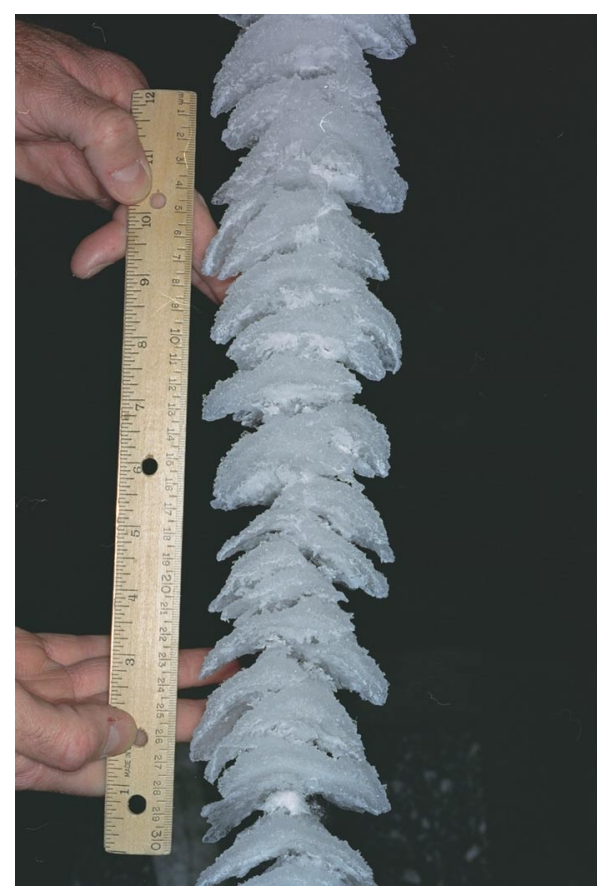

Figure 10. Front view of ice accretion. Run conducted with 1998 spray system. $\Lambda=45^{\circ}$, $\mathrm{V}=250 \quad \mathrm{mph}, \quad \mathrm{T}=25^{\circ} \mathrm{F}, \quad \mathrm{LWC}=0.75 \mathrm{~g} / \mathrm{m}^{3}$, $M V D=20 \mu \mathrm{m}, \tau=10 \mathrm{~min}$. Direction of flow is from bottom to top, scale of ruler is in centimeters and inches.

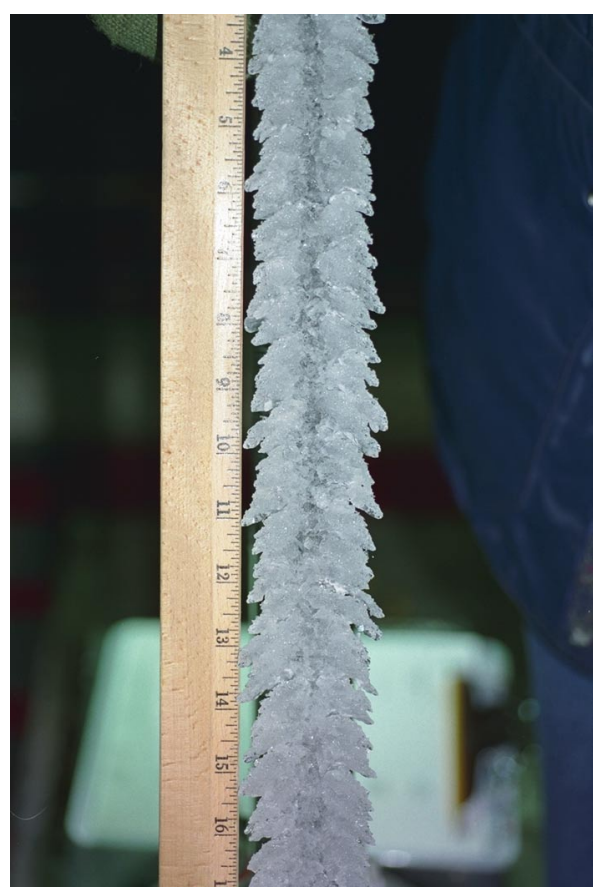

Figure 9. Front view of ice accretion. Run conducted with 1996 spray system. $\Lambda=30^{\circ}$, $\mathrm{V}=200 \quad \mathrm{mph}, \quad \mathrm{T}=25^{\circ} \mathrm{F}, \quad \mathrm{LWC}=0.75 \mathrm{~g} / \mathrm{m}^{3}$ $M V D=20 \mu \mathrm{m}, \tau=10 \mathrm{~min}$. Direction of flow is from bottom to top, scale of ruler is in inches.

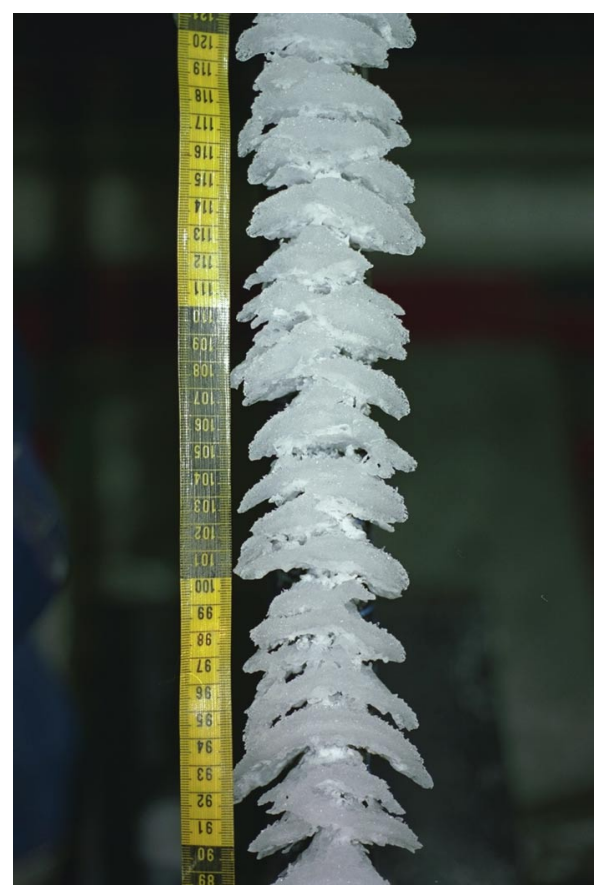

Figure 11. Front view of ice accretion. Run conducted with 1996 spray system. $\Lambda=45^{\circ}$, $\mathrm{V}=250 \quad \mathrm{mph}, \quad \mathrm{T}=25^{\circ} \mathrm{F}, \quad \mathrm{LWC}=0.75 \mathrm{~g} / \mathrm{m}^{3}$, $M V D=20 \mu \mathrm{m}, \tau=10 \mathrm{~min}$. Direction of flow is from bottom to top, scale of ruler is in centimeters, smallest division 1 millimeter. 


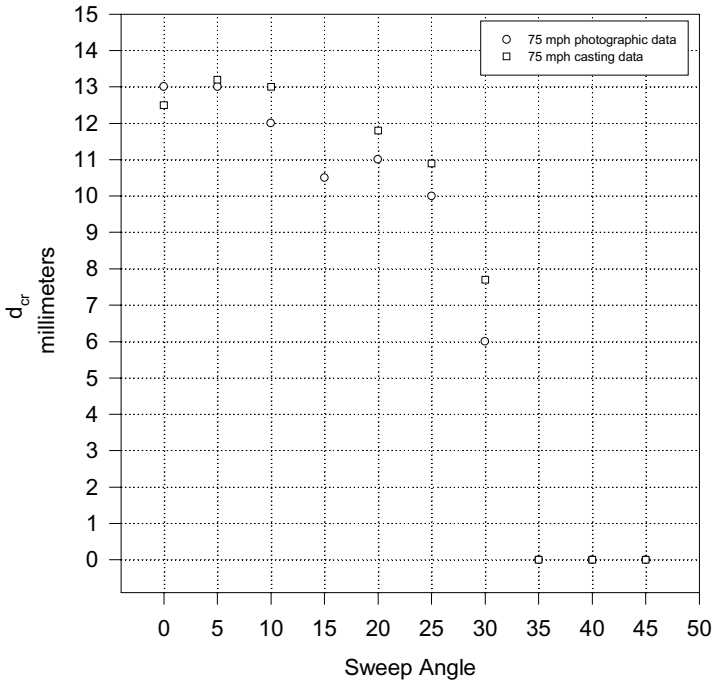

Figure 12. Change in critical distance with sweep angle at a velocity of $75 \mathrm{mph} . \Lambda=0^{\circ}$ to $45^{\circ}$ at $5^{\circ}$ increments, $V=75 \mathrm{mph}, \mathrm{T}=25^{\circ} \mathrm{F}$, $\mathrm{LWC}=0.8 \mathrm{~g} / \mathrm{m}^{3}, \mathrm{MVD}=20 \mu \mathrm{m}, \tau=5 \mathrm{~min}$.

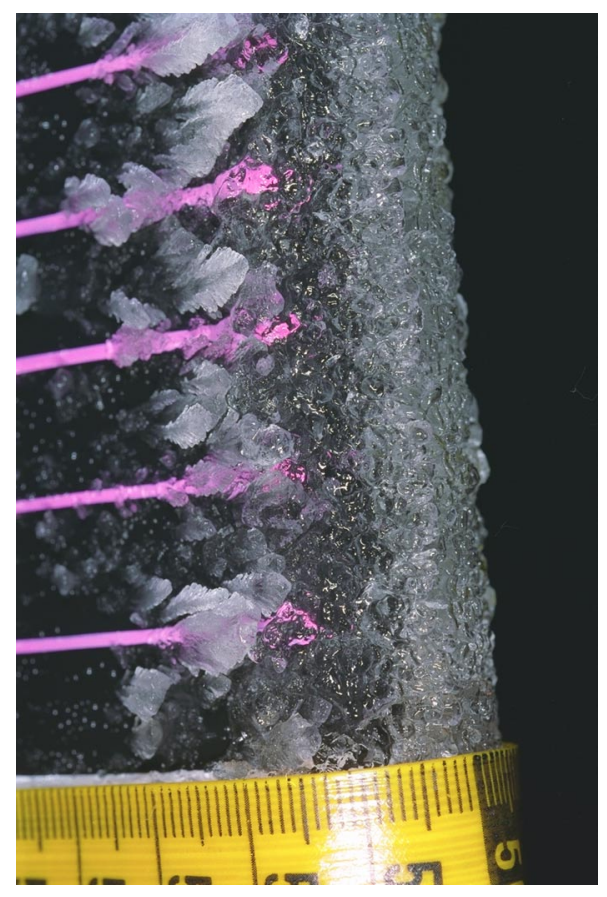

Figure 14. Side view of the glaze ice feathers zone showing the individual feathers with a preferred direction of growth. $\Lambda=0^{\circ}, V=75 \mathrm{mph}$, $\mathrm{T}=25^{\circ} \mathrm{F}, \mathrm{LWC}=0.8 \mathrm{~g} / \mathrm{m}^{3}, \mathrm{MVD}=20 \mu \mathrm{m}, \tau=10 \mathrm{~min}$. Scale of ruler is in centimeters, smallest division 1 millimeter.

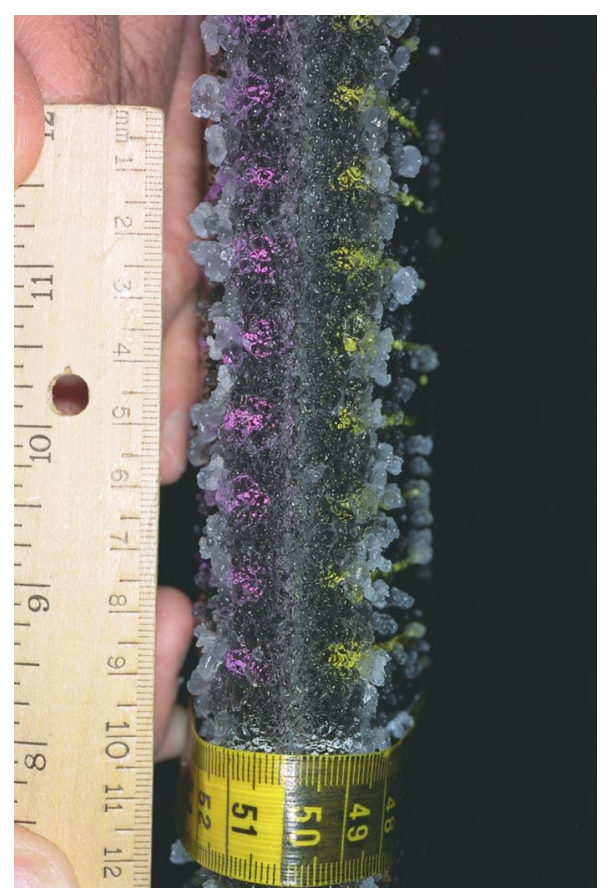

Figure 13. Front view of ice accretion, showing the attachment line zone and the glaze ice feathers zone at $\Lambda=0^{\circ}, V=75 \mathrm{mph}, T=25^{\circ} \mathrm{F}$, $\mathrm{LWC}=0.8 \mathrm{~g} / \mathrm{m}^{3}, \mathrm{MVD}=20 \mu \mathrm{m}, \tau=10 \mathrm{~min}$. Scale of ruler is in centimeters, smallest division 1 millimeter.

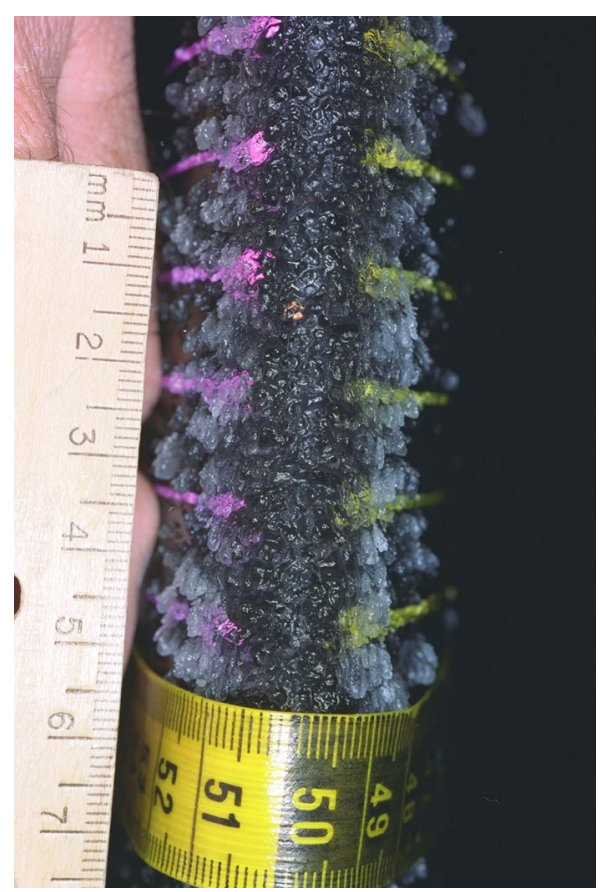

Figure 15. Front view of ice accretion showing the attachment line zone and the glaze ice feathers zone at $\Lambda=30^{\circ}, V=75 \mathrm{mph}, T=25^{\circ} \mathrm{F}$, $\mathrm{LWC}=0.8 \mathrm{~g} / \mathrm{m}^{3}, \mathrm{MVD}=20 \mu \mathrm{m}, \tau=5 \mathrm{~min}$. Direction of flow is from bottom to top, scale of ruler is in centimeters, smallest division 1 millimeter. 


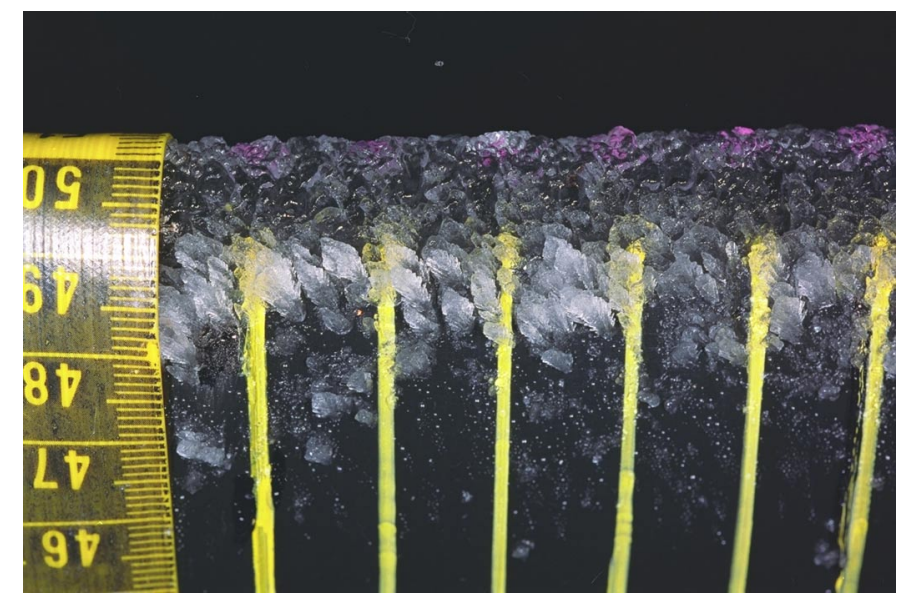

Figure 16. Side view of the ice accretion showing the glaze ice feathers zone at $\Lambda=30^{\circ}$, $\mathrm{V}=75 \quad \mathrm{mph}, \quad \mathrm{T}=25^{\circ} \mathrm{F}, \quad \mathrm{LWC}=0.8 \mathrm{~g} / \mathrm{m}^{3}$, $M V D=20 \mu \mathrm{m}, \tau=5 \mathrm{~min}$. Direction of flow is from left to right, scale of ruler is in centimeters, smallest division 1 millimeter.

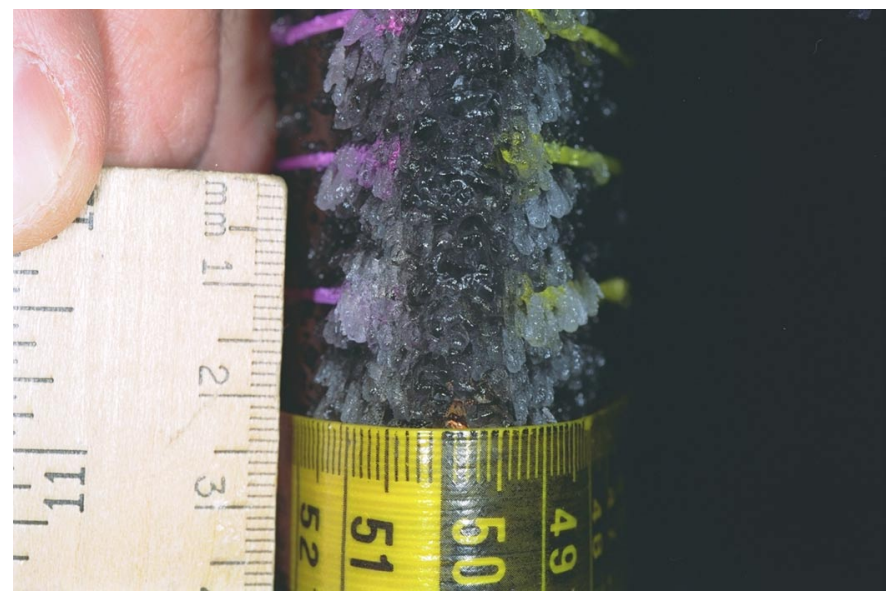

Figure 17. Front view of the ice accretion showing the top part of large feathers along the attachment line area. $\Lambda=35^{\circ}, V=75 \mathrm{mph}$, $\mathrm{T}=25^{\circ} \mathrm{F}, \mathrm{LWC}=0.8 \mathrm{~g} / \mathrm{m}^{3}, \mathrm{MVD}=20 \mu \mathrm{m}, \tau=5 \mathrm{~min}$. Direction of flow is from bottom to top, scale of ruler is in centimeters, smallest division 1 millimeter.

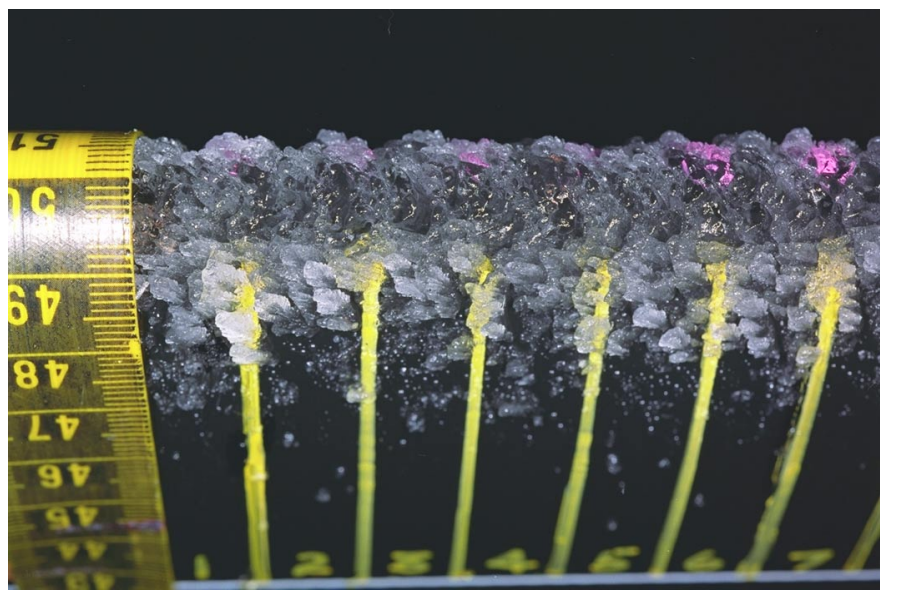

Figure 18. Side view of the ice accretion showing the glaze ice feathers zone and the top part of large feathers along the attachment line area. $\Lambda=35^{\circ}, \quad V=75 \mathrm{mph}, \mathrm{T}=25^{\circ} \mathrm{F}$, $\mathrm{LWC}=0.8 \mathrm{~g} / \mathrm{m}^{3}, \mathrm{MVD}=20 \mu \mathrm{m}, \tau=5 \mathrm{~min}$. Direction of flow is from left to right, scale of ruler is in centimeters, smallest division 1 millimeter.

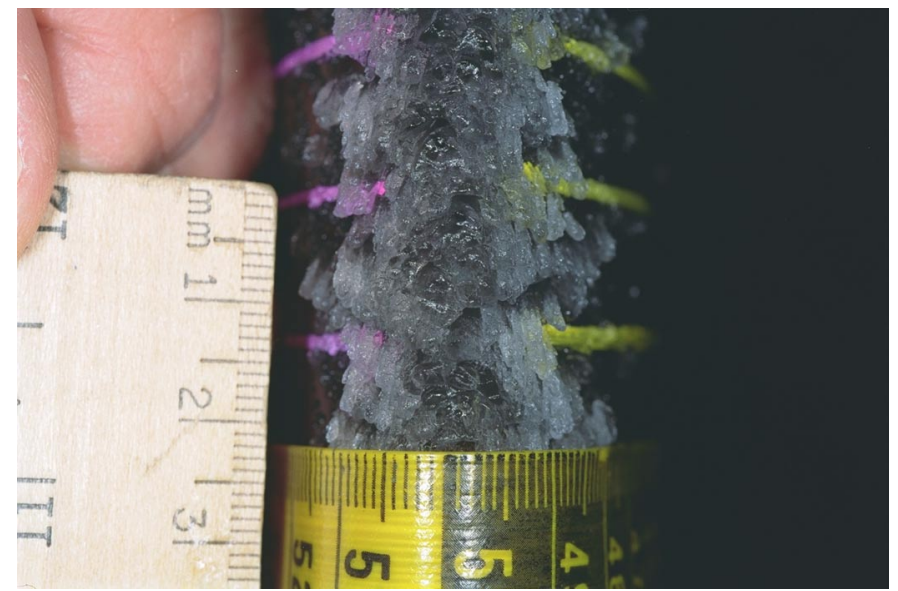

Figure 19. Front view of ice accretion showing the top of large feathers along the attachment line area. $\Lambda=40^{\circ}, V=75 \mathrm{mph}, \quad \mathrm{T}=25^{\circ} \mathrm{F}$, $\mathrm{LWC}=0.8 \mathrm{~g} / \mathrm{m}^{3}, \mathrm{MVD}=20 \mu \mathrm{m}, \tau=5 \mathrm{~min}$. Direction of flow is from bottom to top, scale of ruler is in centimeters, smallest division is 1 millimeter. 

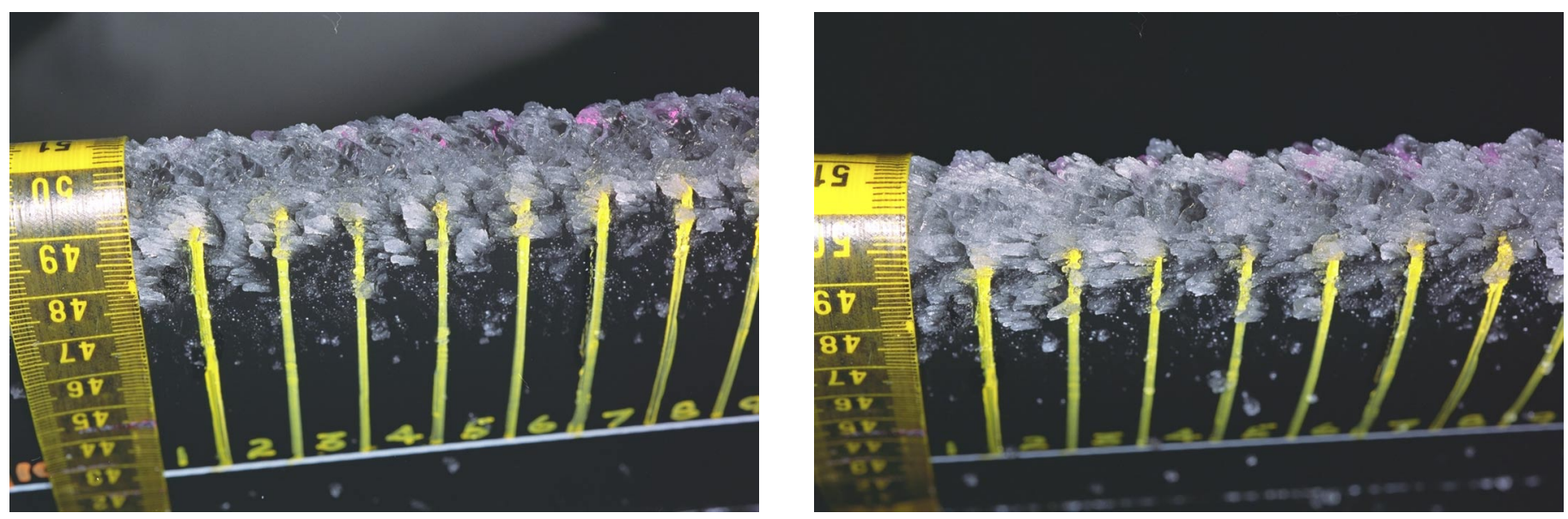

Figure 20. Side view of the ice accretion showing the top of large feathers along the attachment line area. $\Lambda=40^{\circ}, V=75 \mathrm{mph}$, $\mathrm{T}=25^{\circ} \mathrm{F}, \mathrm{LWC}=0.8 \mathrm{~g} / \mathrm{m}^{3}, \mathrm{MVD}=20 \mu \mathrm{m}, \tau=5 \mathrm{~min}$. Direction of flow is from left to right, scale of ruler is in centimeters, smallest division 1 millimeter.

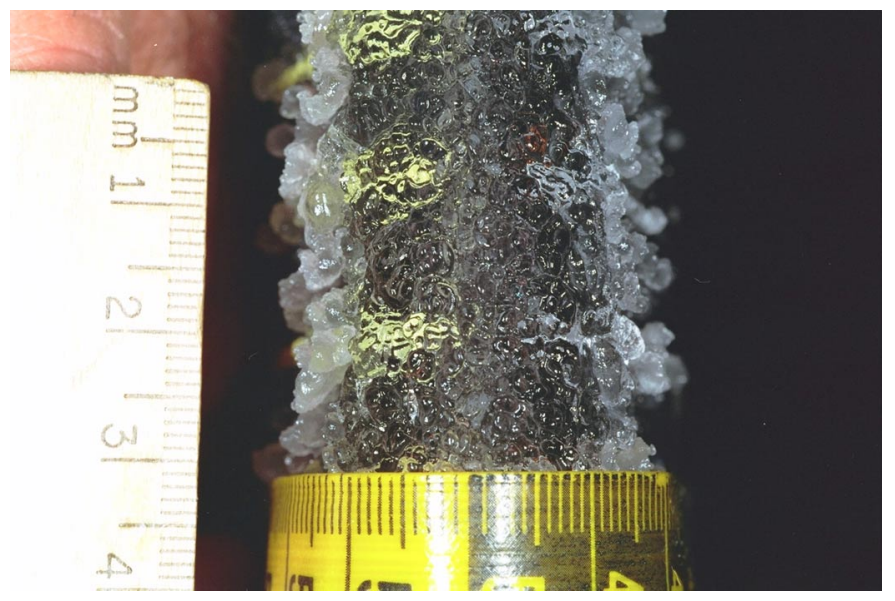

Figure 22. Front view of the ice accretion showing the attachment line zone, and the glaze ice feathers zone. The orientation of the preferred direction of growth of the feathers can be observed. $\Lambda=10^{\circ}, V=75 \mathrm{mph}, \mathrm{T}=25^{\circ} \mathrm{F}$, $\mathrm{LWC}=0.8 \mathrm{~g} / \mathrm{m}^{3}, \mathrm{MVD}=20 \mu \mathrm{m}, \tau=10 \mathrm{~min}$. Direction of flow is from bottom to top, scale of ruler is in centimeters, smallest division 1 millimeter.

Figure 21. Side view of the ice accretion showing the top of large feathers along the attachment line area. $\Lambda=45^{\circ}, V=75 \mathrm{mph}$, $\mathrm{T}=25^{\circ} \mathrm{F}, \mathrm{LWC}=0.8 \mathrm{~g} / \mathrm{m}^{3}, \mathrm{MVD}=20 \mu \mathrm{m}, \tau=5 \mathrm{~min}$. Direction of flow is from left to right, scale of ruler is in centimeters, smallest division 1 millimeter.

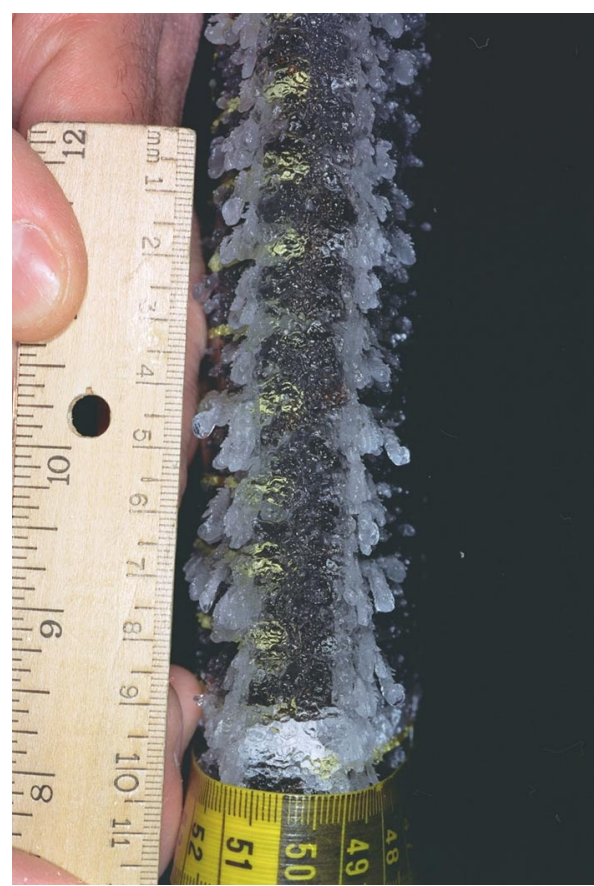

Figure 23. Front view of the ice accretion showing the orientation of the preferred direction of growth of the feathers. $\Lambda=15^{\circ}, V=75$ $\mathrm{mph}, \quad \mathrm{T}=25^{\circ} \mathrm{F}, \quad \mathrm{LWC}=0.8 \mathrm{~g} / \mathrm{m}^{3}, \quad \mathrm{MVD}=20 \mu \mathrm{m}$, $\tau=10 \mathrm{~min}$. Direction of flow is from bottom to top, scale of ruler is in centimeters, smallest division 1 millimeter. 


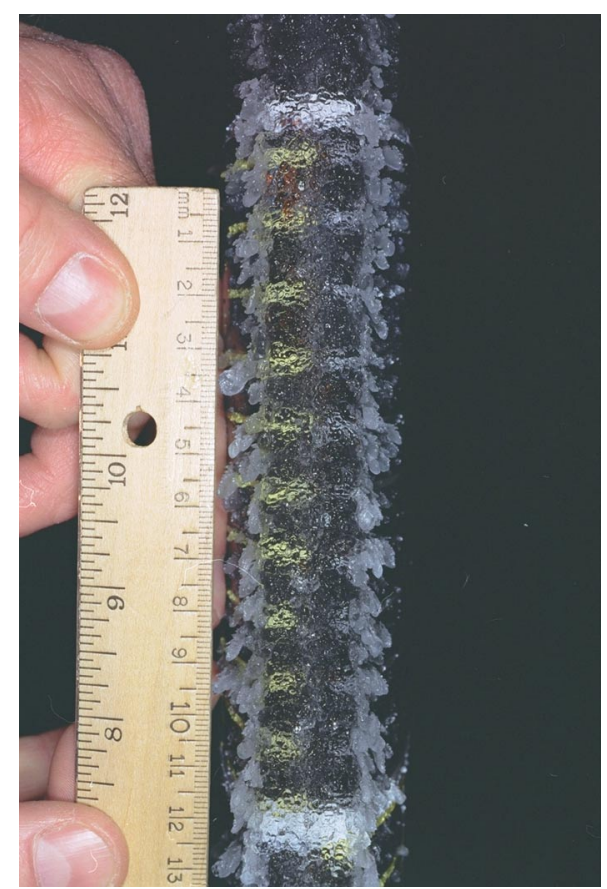

Figure 24. Front view of ice accretion showing the orientation of the preferred direction of growth of the feathers. $\Lambda=20^{\circ}, V=75 \mathrm{mph}$, $\mathrm{T}=25^{\circ} \mathrm{F}, \mathrm{LWC}=0.8 \mathrm{~g} / \mathrm{m}^{3}, \mathrm{MVD}=20 \mu \mathrm{m}, \tau=10 \mathrm{~min}$. Direction of flow is from bottom to top, scale of ruler is in centimeters and inches.

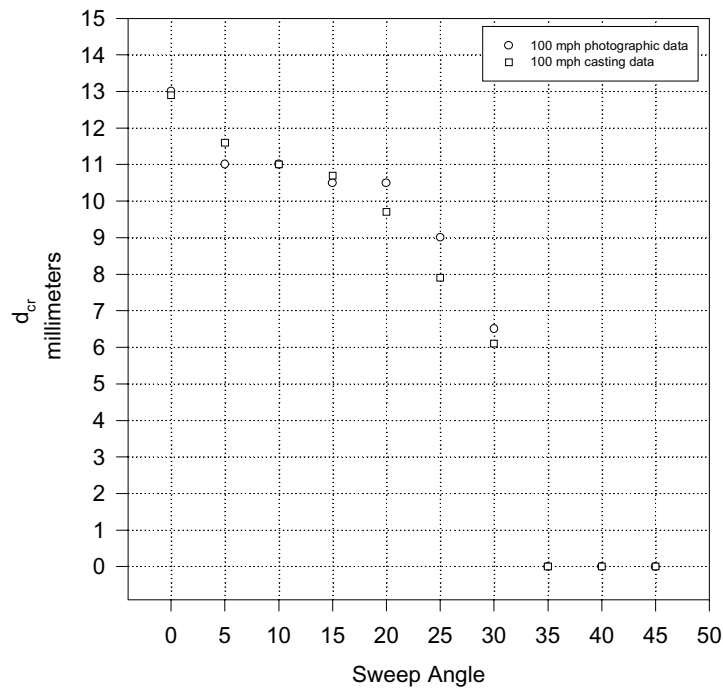

Figure 26. Change in critical distance with sweep angle at a velocity of $100 \mathrm{mph} . \Lambda=0^{\circ}$ to $45^{\circ}$ at $5^{\circ}$ increments, $\mathrm{V}=100 \mathrm{mph}, \mathrm{T}=25^{\circ} \mathrm{F}$, $\mathrm{LWC}=0.8 \mathrm{~g} / \mathrm{m}^{3}, \mathrm{MVD}=20 \mu \mathrm{m}, \tau=5 \mathrm{~min}$.

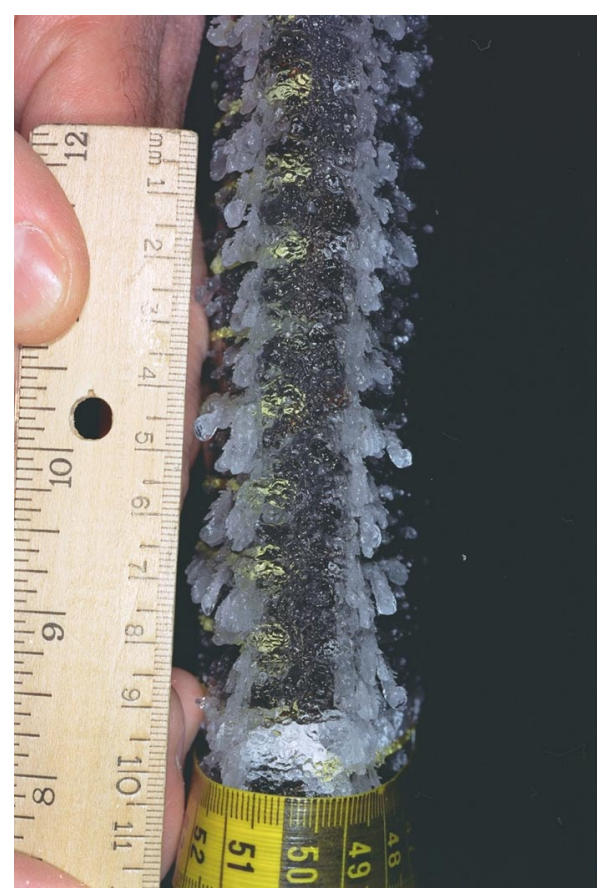

Figure 25. Front view of ice accretion showing the feathers forming scallop tips. $\Lambda=30^{\circ}$, $\mathrm{V}=75 \quad \mathrm{mph}, \quad \mathrm{T}=25^{\circ} \mathrm{F}, \quad \mathrm{LWC}=0.8 \mathrm{~g} / \mathrm{m}^{3}$, $M V D=20 \mu \mathrm{m}, \tau=10 \mathrm{~min}$. Direction of flow is from bottom to top, scale of ruler is in centimeters, smallest division 1 millimeter.

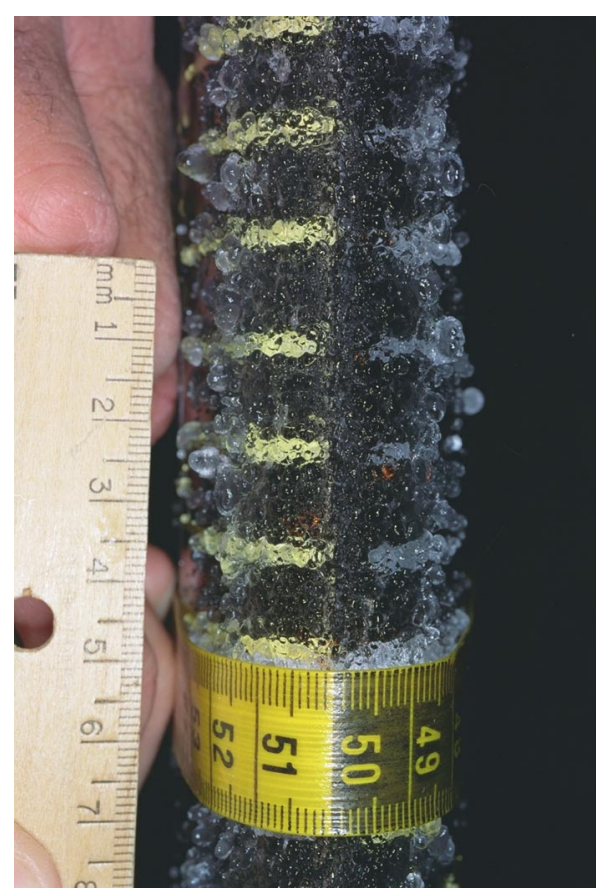

Figure 27. Front view of the ice accretion showing the attachment line zone and the glaze ice feathers zone. $\Lambda=0^{\circ}, V=100 \mathrm{mph}$, $\mathrm{T}=25^{\circ} \mathrm{F}, \mathrm{LWC}=0.75 \mathrm{~g} / \mathrm{m}^{3}, \mathrm{MVD}=20 \mu \mathrm{m}, \tau=5 \mathrm{~min}$. Scale of ruler is in centimeters, smallest division 1 millimeter. 


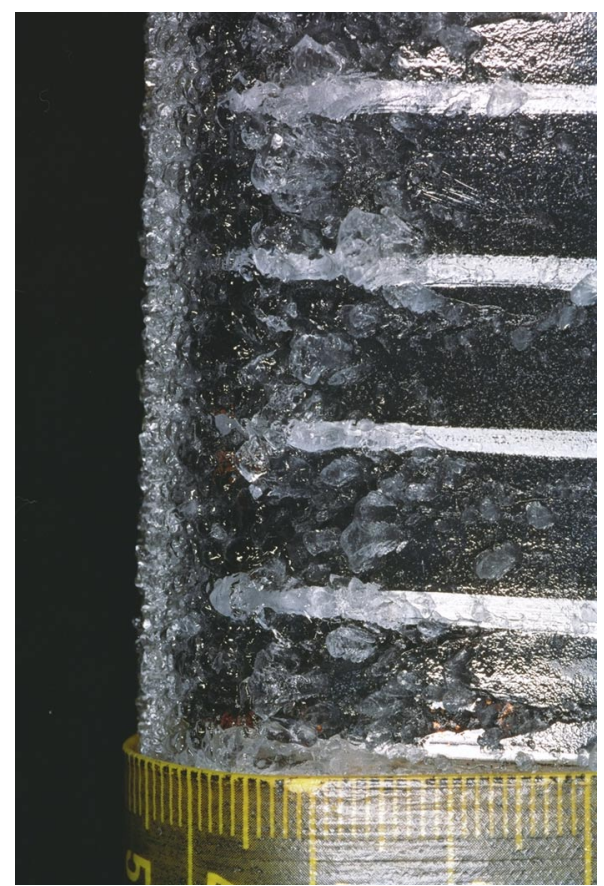

Figure 28. Side view of ice accretion showing individual feathers in the glaze ice feathers zone. $\quad \Lambda=0^{\circ}, \quad \mathrm{V}=100 \mathrm{mph}, \quad \mathrm{T}=25^{\circ} \mathrm{F}$, $\mathrm{LWC}=0.75 \mathrm{~g} / \mathrm{m}^{3}, \mathrm{MVD}=20 \mu \mathrm{m}, \tau=5 \mathrm{~min}$. Scale of ruler is in centimeters, smallest division 1 millimeter.

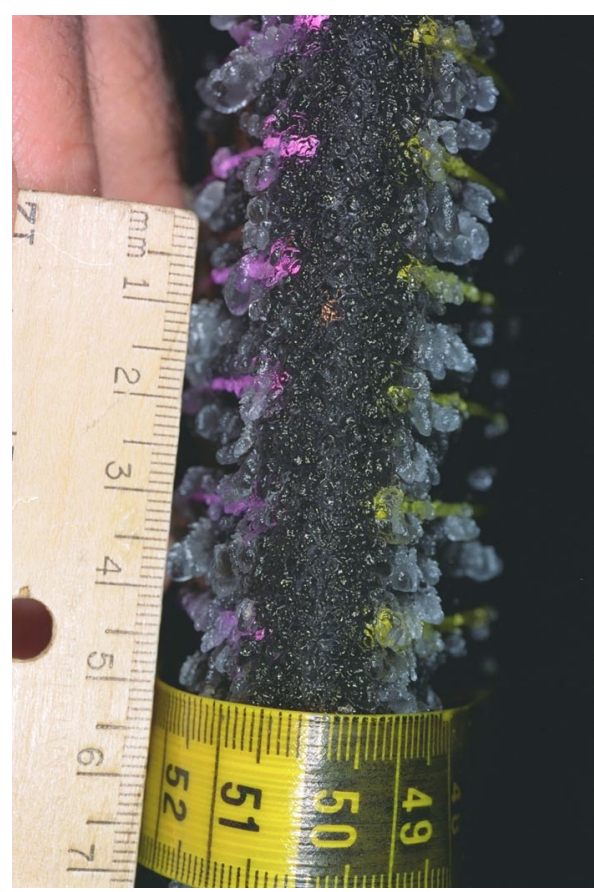

Figure 29. Front view of ice accretion showing the attachment line zone and the glaze ice feathers zone. $\Lambda=25^{\circ}, V=100 \mathrm{mph}, \mathrm{T}=25^{\circ} \mathrm{F}$, $\mathrm{LWC}=0.75 \mathrm{~g} / \mathrm{m}^{3}, \mathrm{MVD}=20 \mu \mathrm{m}, \tau=5 \mathrm{~min}$. Direction of flow is from bottom to top, scale of ruler is in centimeters, smallest division 1millimeter.

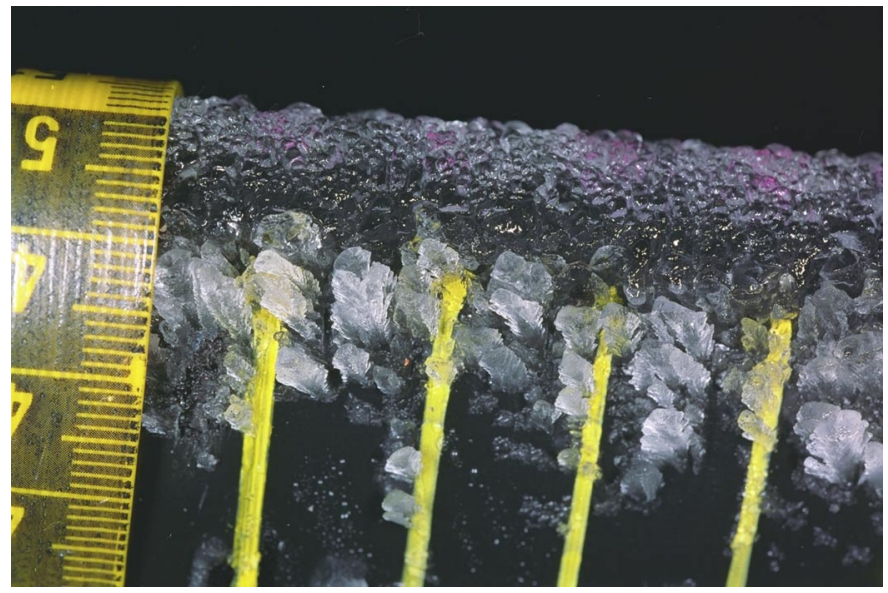

Figure 30. Side view of ice accretion showing the feathers in the glaze ice feathers zone. $\Lambda=25^{\circ}, V=100 \mathrm{mph}, T=25^{\circ} \mathrm{F}, \mathrm{LWC}=0.75 \mathrm{~g} / \mathrm{m}^{3}$, $M V D=20 \mu \mathrm{m}, \tau=5 \mathrm{~min}$. Direction of flow is from left to right, scale of ruler is in centimeters, smallest division 1 millimeter.

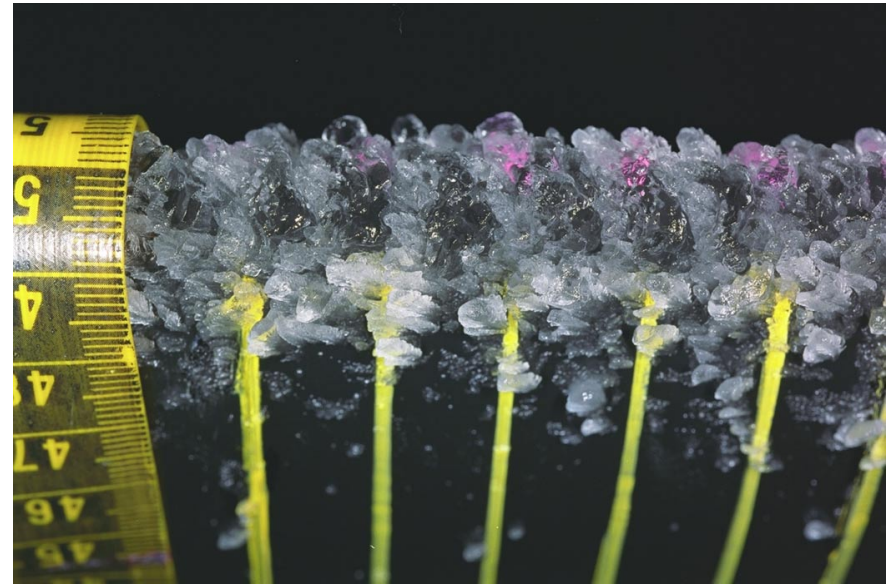

Figure 31. Side view of the ice accretion showing the top of large feathers along the attachment line area. $\Lambda=35^{\circ}, V=100 \mathrm{mph}$, $\mathrm{T}=25^{\circ} \mathrm{F}, \mathrm{LWC}=0.75 \mathrm{~g} / \mathrm{m}^{3}, \mathrm{MVD}=20 \mu \mathrm{m}, \tau=5 \mathrm{~min}$. Direction of flow is from left to right, scale of ruler is in centimeters, smallest division 1 millimeter. 


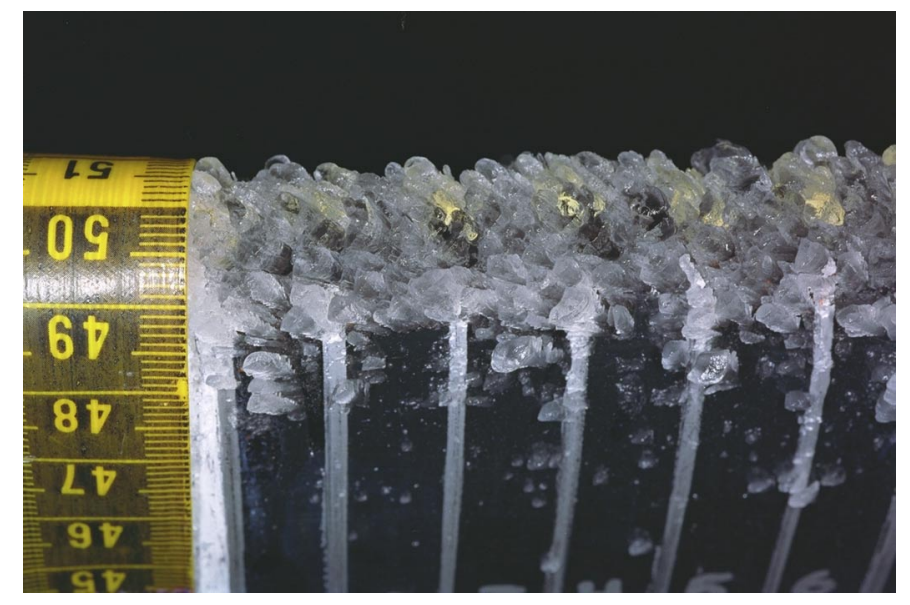

Figure 32. Side view of ice accretion showing large feathers along the attachment line area. $\Lambda=40^{\circ}, V=100 \mathrm{mph}, T=25^{\circ} \mathrm{F}, L W C=0.75 \mathrm{~g} / \mathrm{m}^{3}$, $M V D=20 \mu \mathrm{m}, \tau=5 \mathrm{~min}$. Direction of flow is from left to right, scale of ruler is in centimeters, smallest division 1 millimeter.

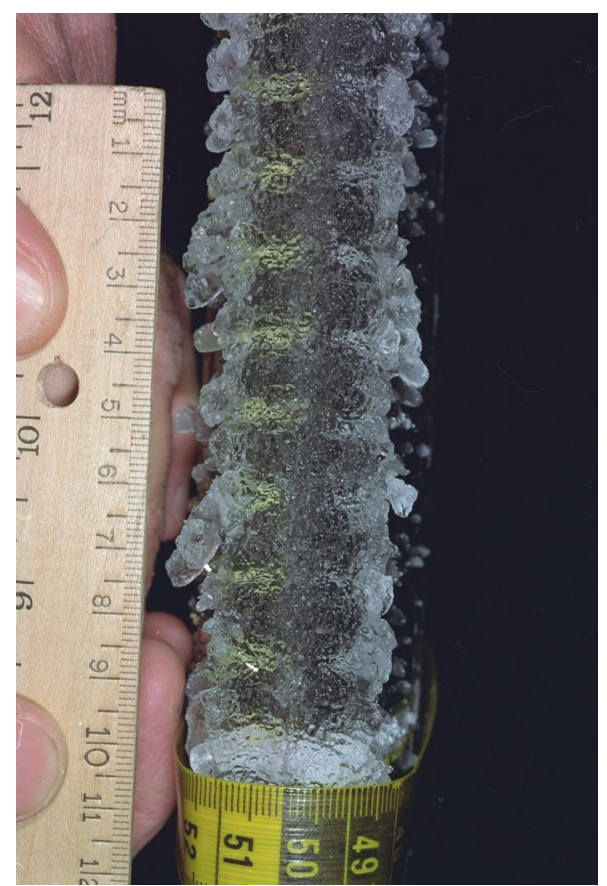

Figure 34. Front view of ice accretion showing the ice of the attachment line zone covering most of the feathers in the glaze ice feathers zone. $\quad \Lambda=15^{\circ}, \quad V=100 \mathrm{mph}, \quad \mathrm{T}=25^{\circ} \mathrm{F}$, $\mathrm{LWC}=0.75 \mathrm{~g} / \mathrm{m}^{3}, \mathrm{MVD}=20 \mu \mathrm{m}, \tau=10 \mathrm{~min}$. Direction of flow is from bottom to top, scale of ruler is in centimeters, smallest division 1 millimeter.

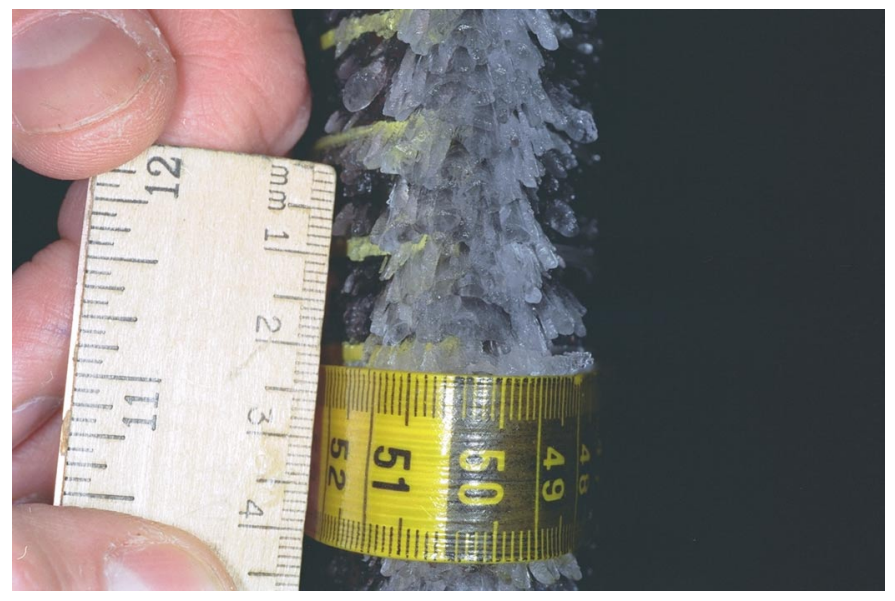

Figure 33. Complete scallop at $\Lambda=45^{\circ}, V=100$ $\mathrm{mph}, \mathrm{T}=25^{\circ} \mathrm{F}, \quad \mathrm{LWC}=0.75 \mathrm{~g} / \mathrm{m}^{3}, \quad \mathrm{MVD}=20 \mu \mathrm{m}$, $\tau=5 \mathrm{~min}$. Direction of flow is from bottom to top scale of ruler is in centimeters, smallest division 1 millimeter.

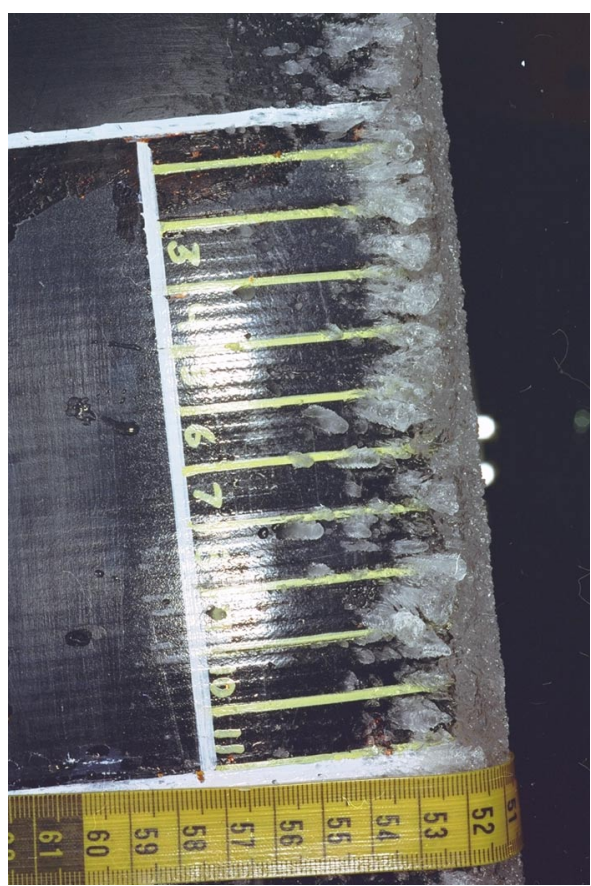

Figure 35. Side view of ice accretion showing the feathers in the glaze ice feathers zone. $\Lambda=15^{\circ}, V=100 \mathrm{mph}, \mathrm{T}=25^{\circ} \mathrm{F}, \mathrm{LWC}=0.75 \mathrm{~g} / \mathrm{m}^{3}$, $M V D=20 \mu \mathrm{m}, \tau=10 \mathrm{~min}$. Direction of flow is from bottom to top, scale of ruler is in centimeters, smallest division 1 millimeter. 


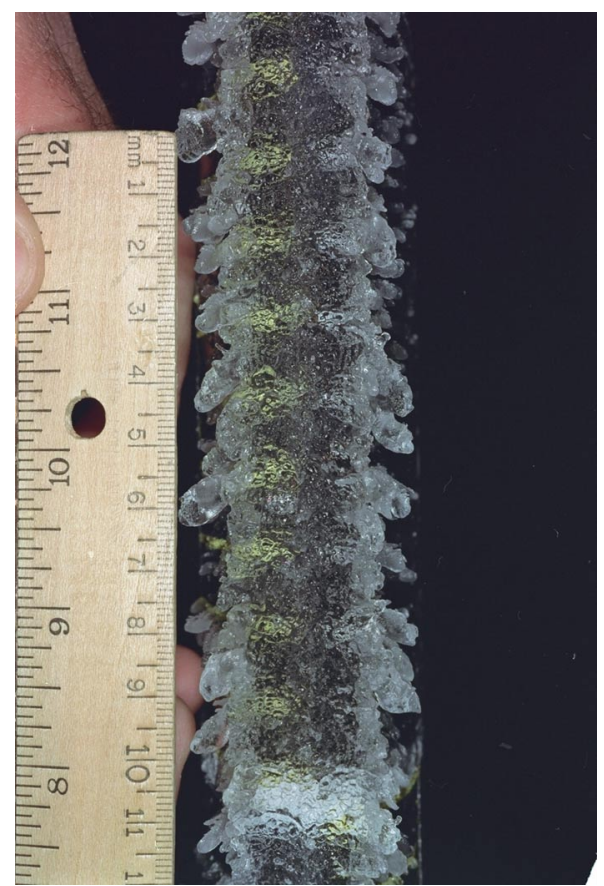

Figure 36. Front view of ice accretion showing the formation of scallop tips. $\Lambda=25^{\circ}$, $\mathrm{V}=100 \quad \mathrm{mph}, \quad \mathrm{T}=25^{\circ} \mathrm{F}, \quad \mathrm{LWC}=0.75 \mathrm{~g} / \mathrm{m}^{3}$, $M V D=20 \mu \mathrm{m}, \tau=10 \mathrm{~min}$. Direction of flow is from bottom to top, scale of ruler is in centimeters, smallest division 1 millimeter.

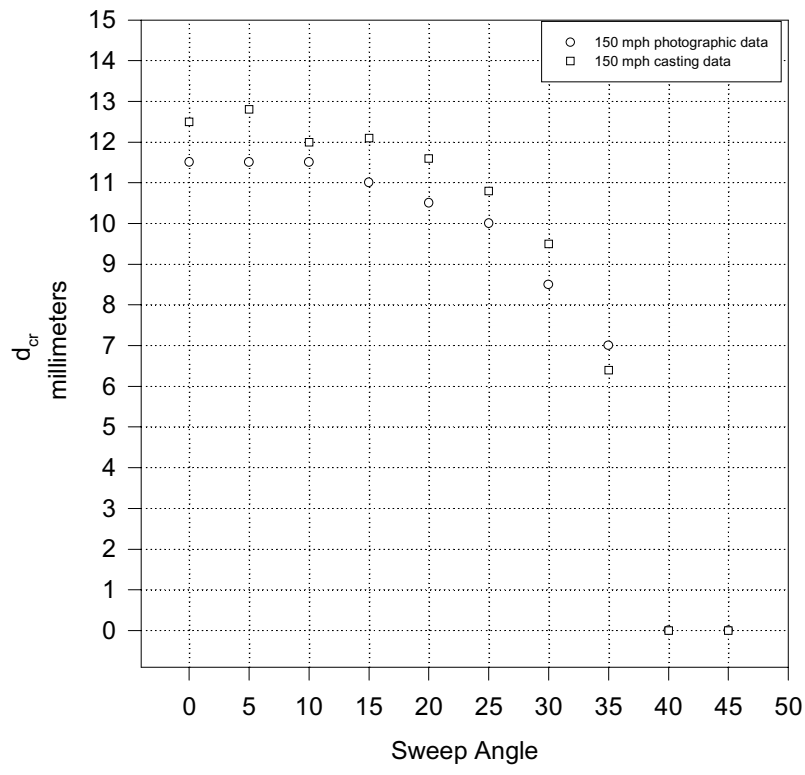

Figure 37. Change in critical distance with sweep angle at a velocity of $150 \mathrm{mph} . \Lambda=0^{\circ}$ to $45^{\circ}$ at $5^{\circ}$ increments, $V=150 \mathrm{mph}, \mathrm{T}=25^{\circ} \mathrm{F}$, $\mathrm{LWC}=0.8 \mathrm{~g} / \mathrm{m}^{3}, \mathrm{MVD}=20 \mu \mathrm{m}, \tau=5 \mathrm{~min}$.

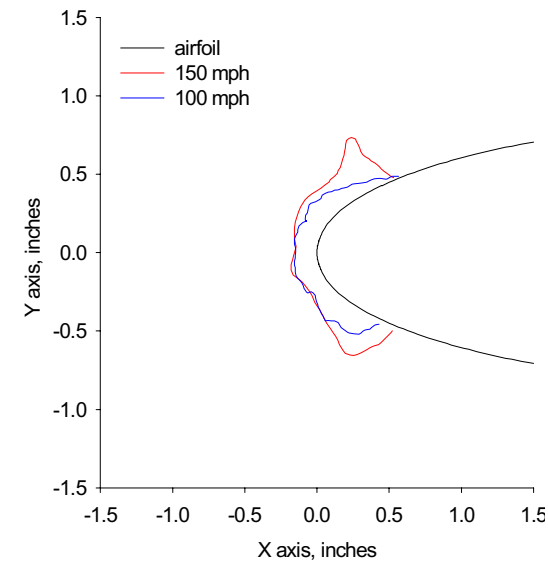

$$
\Lambda=0^{\circ}
$$

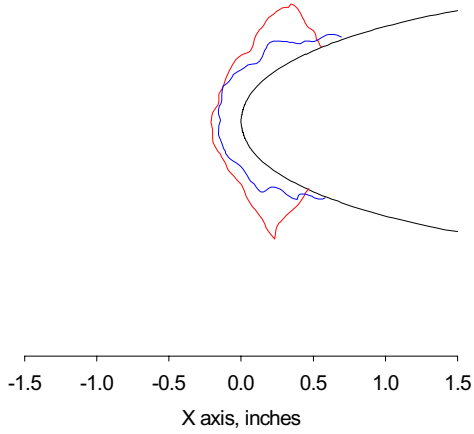

$\Lambda=$

$20^{\circ}$
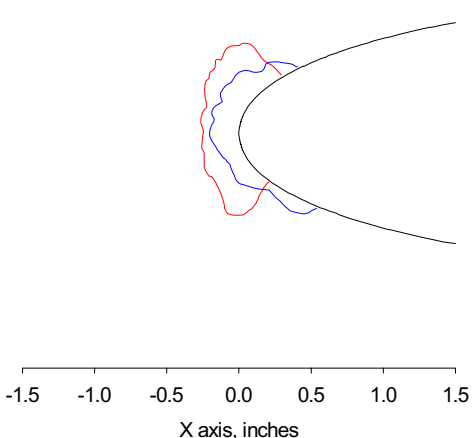

$\Lambda=$

$40^{\circ}$

Figure 38. Pencil tracings of the ice shapes for sweep angles of $0^{\circ}, 20^{\circ}$, and $40^{\circ}$, at velocities of 100 and $150 \mathrm{mph}$. 


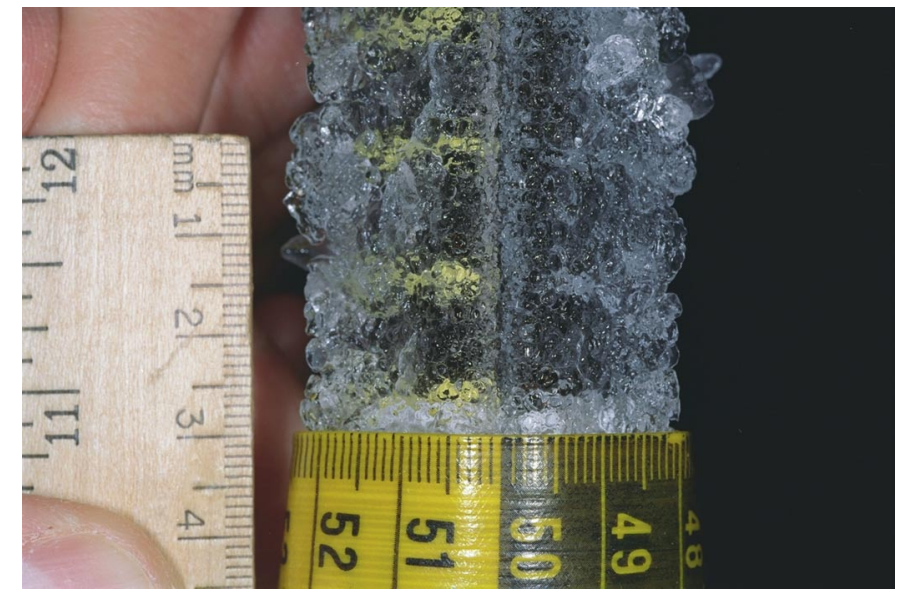

Figure 39. Front view of ice accretion showing the attachment line zone and the glaze ice feathers zone. $\Lambda=0^{\circ}, V=150 \mathrm{mph}, T=25^{\circ} \mathrm{F}$, $L W C=0.75 \mathrm{~g} / \mathrm{m}^{3}, M V D=20 \mu \mathrm{m}, \tau=5 \mathrm{~min}$. Scale of ruler is in centimeters, smallest division 1 millimeter.

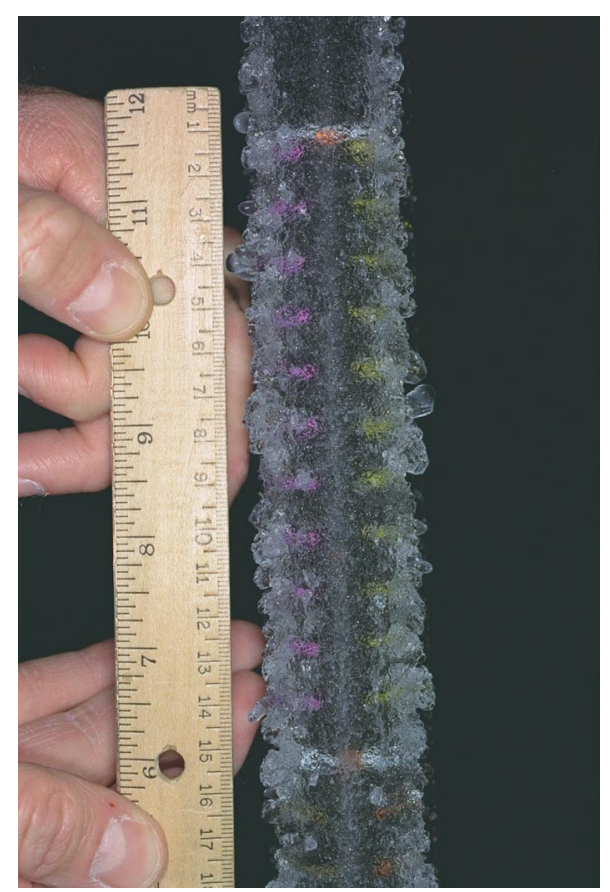

Figure 41. Front view of ice accretion showing the attachment line zone and the glaze ice feathers zone, with the feathers not forming scallop tips. $\Lambda=10^{\circ}, V=150 \mathrm{mph}, T=25^{\circ} \mathrm{F}$, $\mathrm{LWC}=0.75 \mathrm{~g} / \mathrm{m}^{3}, \mathrm{MVD}=20 \mu \mathrm{m}, \tau=5 \mathrm{~min}$. Direction of flow is from bottom to top, scale of ruler is in centimeters, smallest division 1 millimeter.

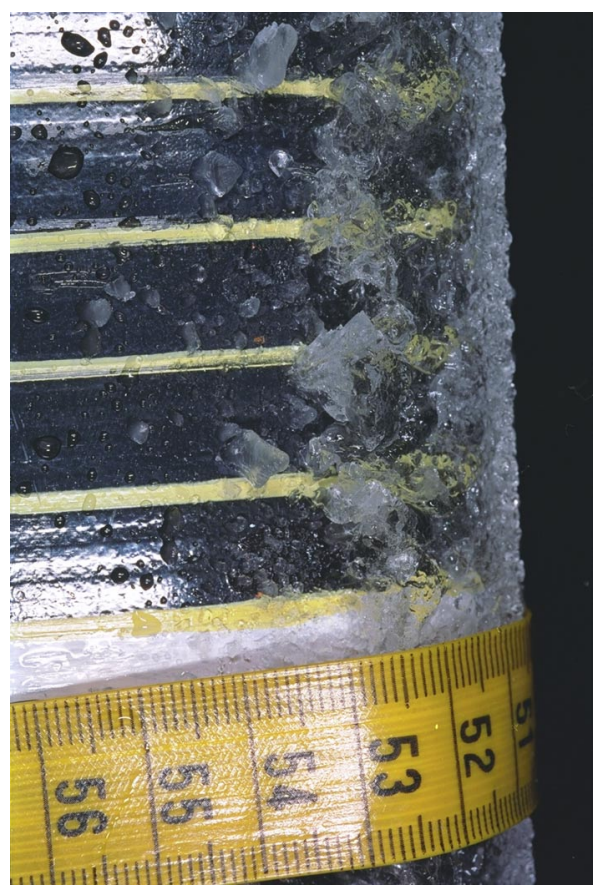

Figure 40. Side view of the ice accretion showing the ice of the attachment line zone covering the feathers in the glaze ice feathers zone. $\quad \Lambda=0^{\circ}, \quad V=150 \mathrm{mph}, \quad \mathrm{T}=25^{\circ} \mathrm{F}$, $\mathrm{LWC}=0.75 \mathrm{~g} / \mathrm{m}^{3}, \mathrm{MVD}=20 \mu \mathrm{m}, \tau=5 \mathrm{~min}$. Scale of ruler is in centimeters, smallest division 1 millimeter.

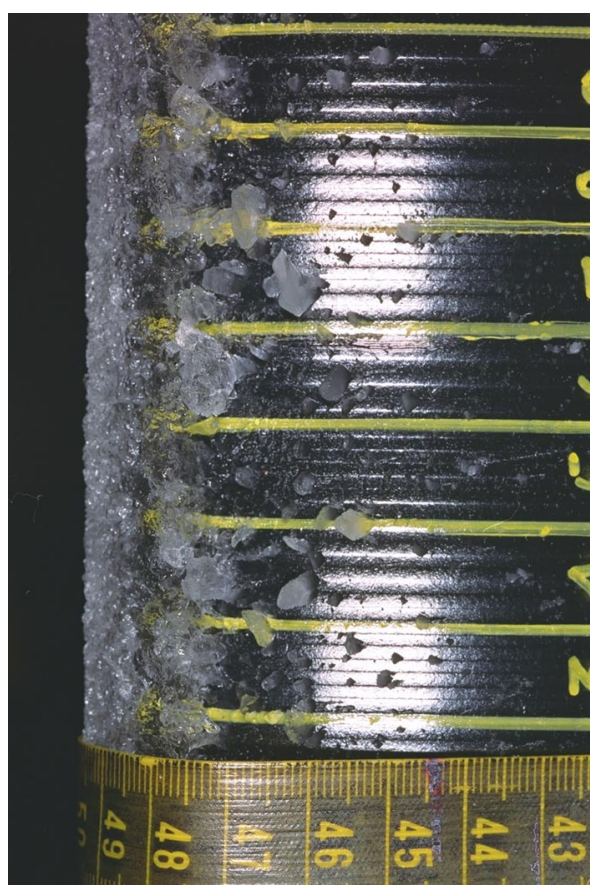

Figure 42. Side view of ice accretion showing the ice of the attachment line zone covering the feathers. $\Lambda=10^{\circ}, V=150 \mathrm{mph}, T=25^{\circ} \mathrm{F}$, $\mathrm{LWC}=0.75 \mathrm{~g} / \mathrm{m}^{3}, M V D=20 \mu \mathrm{m}, \tau=5 \mathrm{~min}$. Direction of flow is from bottom to top, scale of ruler is in centimeters, smallest division 1 millimeter. 


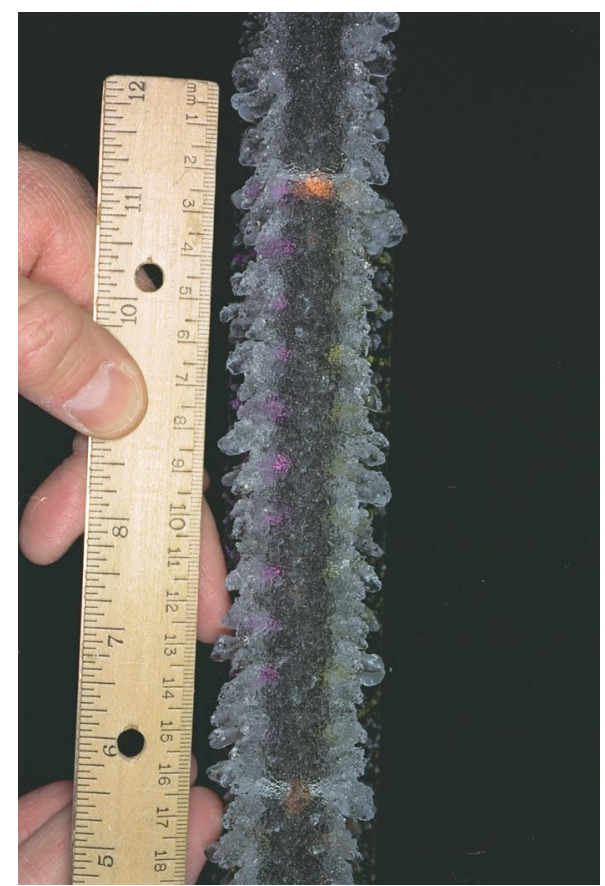

Figure 43. Front view of ice accretion showing the formation of scallop tips. $\Lambda=25^{\circ}, V=150$ $\mathrm{mph}, \mathrm{T}=25^{\circ} \mathrm{F}, \quad \mathrm{LWC}=0.75 \mathrm{~g} / \mathrm{m}^{3}, \mathrm{MVD}=20 \mu \mathrm{m}$, $\tau=5 \mathrm{~min}$. Direction of flow is from bottom to top, scale of ruler is in centimeters, smallest division 1 millimeter.

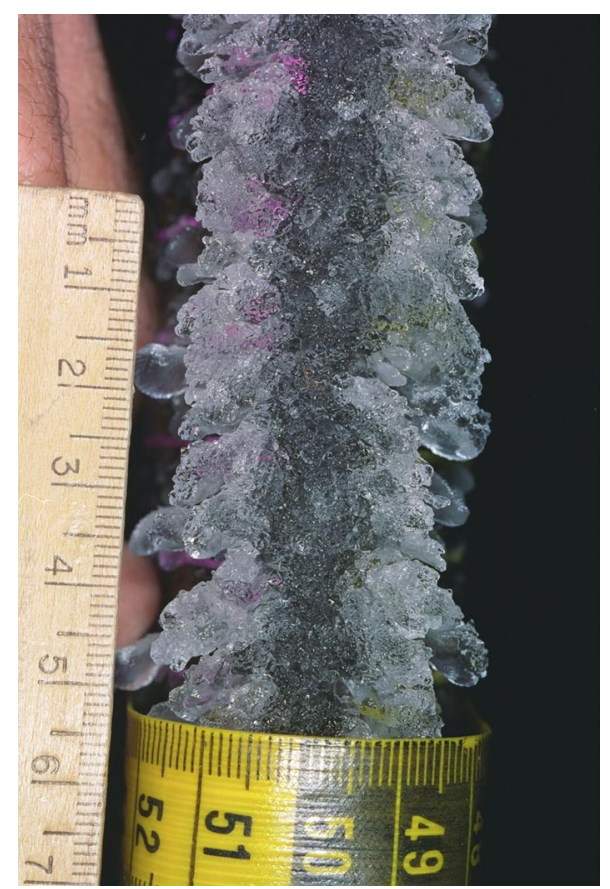

Figure 45. Front view of ice accretion showing scallop tips and the attachment line zone. $\Lambda=35^{\circ}, V=150 \mathrm{mph}, \mathrm{T}=25^{\circ} \mathrm{F}, \mathrm{LWC}=0.75 \mathrm{~g} / \mathrm{m}^{3}$, $M V D=20 \mu \mathrm{m}, \tau=5 \mathrm{~min}$. Direction of flow is from bottom to top, scale of ruler is in centimeters, smallest division 1 millimeter.

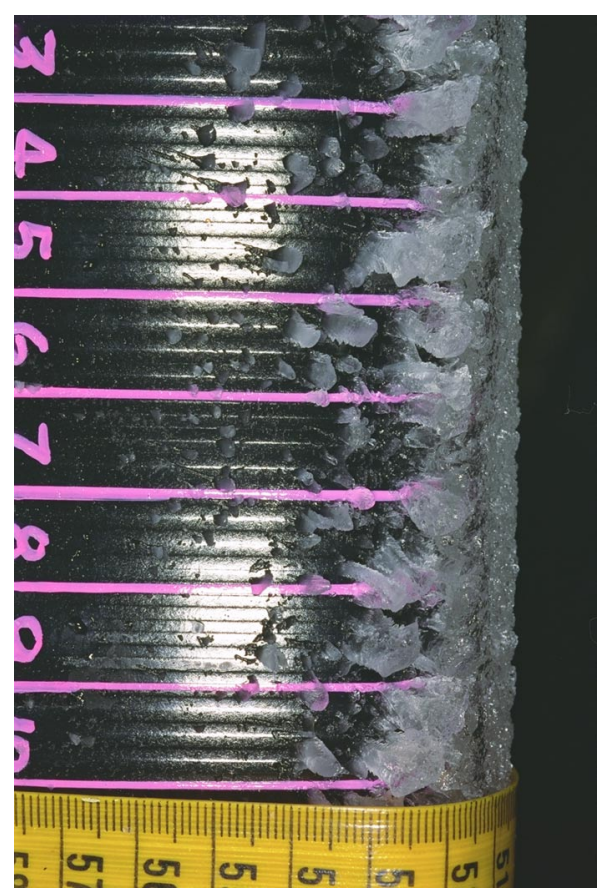

Figure 44. Side view of the ice accretion showing the feathers in the glaze ice feathers zone forming scallop tips. $\Lambda=25^{\circ}, V=150 \mathrm{mph}$, $\mathrm{T}=25^{\circ} \mathrm{F}, \mathrm{LWC}=0.75 \mathrm{~g} / \mathrm{m}^{3}, \mathrm{MVD}=20 \mu \mathrm{m}, \tau=5 \mathrm{~min}$. Direction of flow is from bottom to top, upper scale of ruler is in centimeters, smallest division 1 millimeter.

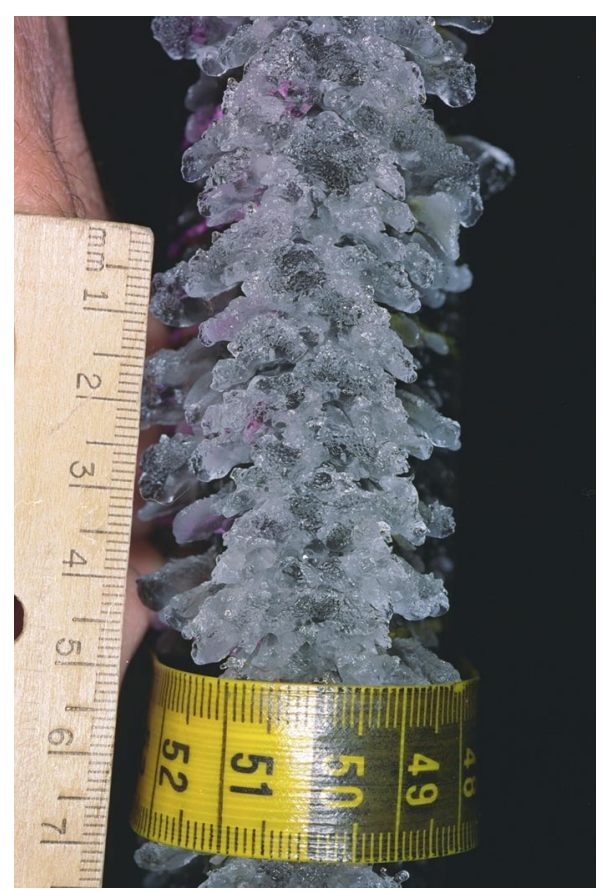

Figure 46. Complete scallop at $\Lambda=40^{\circ}, V=150$ $\mathrm{mph}, \mathrm{T}=25^{\circ} \mathrm{F}, \quad \mathrm{LWC}=0.75 \mathrm{~g} / \mathrm{m}^{3}, \quad \mathrm{MVD}=20 \mu \mathrm{m}$, $\tau=5 \mathrm{~min}$. Direction of flow is from bottom to top, scale of ruler is in centimeters, smallest division 1 millimeter. 


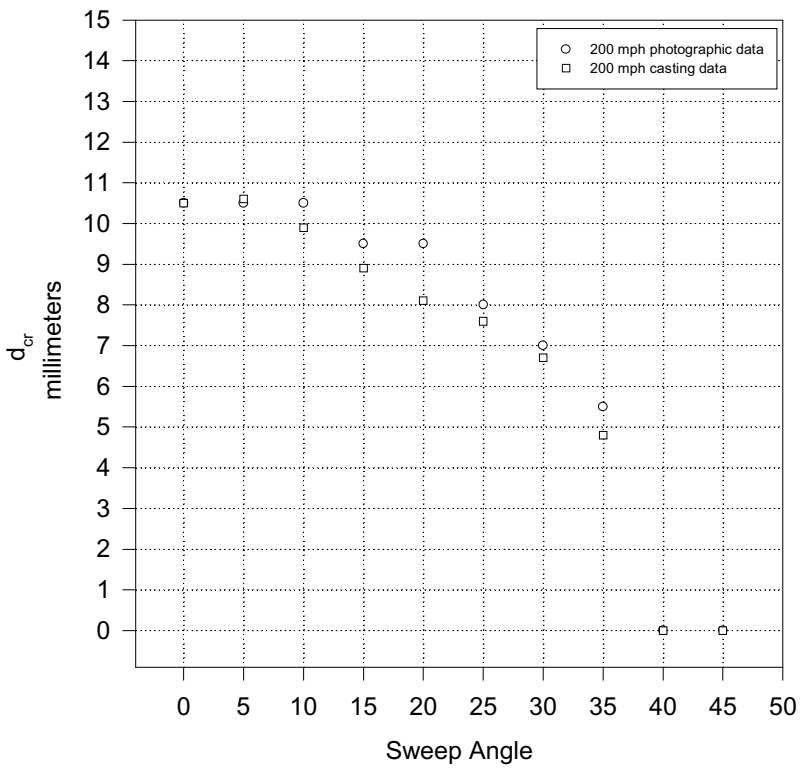

Figure 47. Change in critical distance with sweep angle at a velocity of $200 \mathrm{mph}$. $\Lambda=0^{\circ}$ to $45^{\circ}$ at $5^{\circ}$ increments, $V=200 \mathrm{mph}, \mathrm{T}=25^{\circ} \mathrm{F}$, $\mathrm{LWC}=0.8 \mathrm{~g} / \mathrm{m}^{3}, \mathrm{MVD}=20 \mu \mathrm{m}, \tau=5 \mathrm{~min}$.

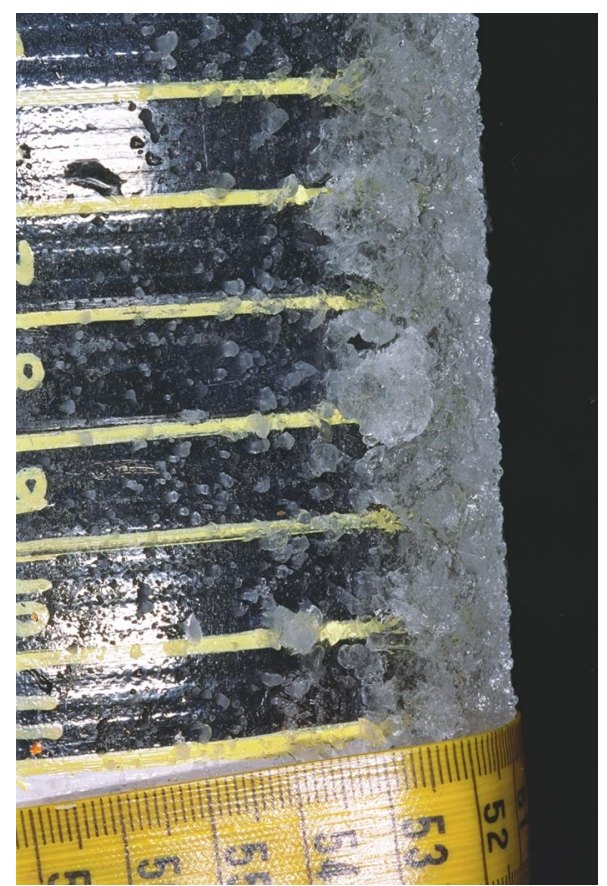

Figure 49. Side view of ice accretion showing the ice of the attachment line zone covering the feathers in the glaze ice feathers zone. $\Lambda=0^{\circ}, \quad \mathrm{V}=200 \mathrm{mph}, \mathrm{T}=25^{\circ} \mathrm{F}, \mathrm{LWC}=0.75 \mathrm{~g} / \mathrm{m}^{3}$, $M V D=20 \mu \mathrm{m}, \tau=5 \mathrm{~min}$. Scale of ruler is in centimeters, smallest division 1 millimeter.

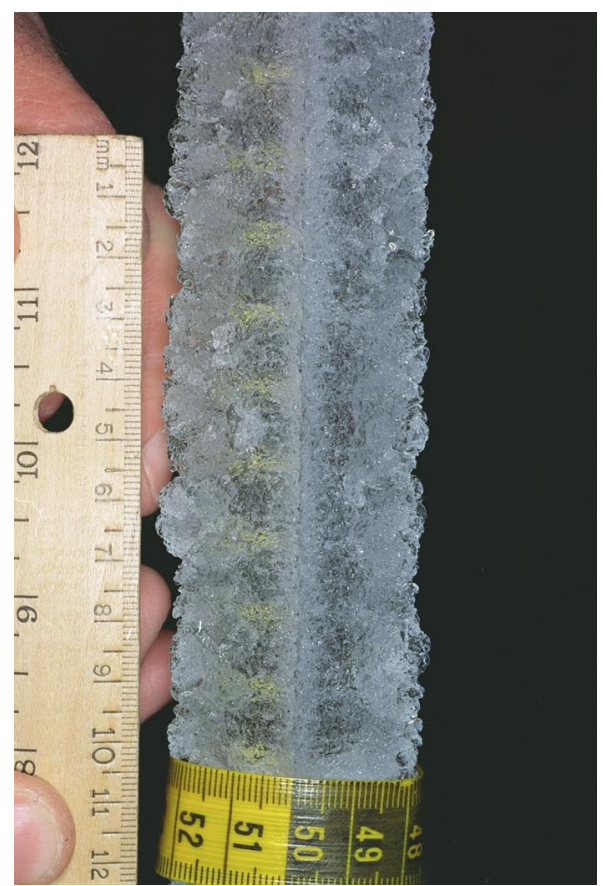

Figure 48. Front view of ice accretion showing the attachment line zone and the glaze ice feathers zone. $\Lambda=0^{\circ}, V=200 \mathrm{mph}, \mathrm{T}=25^{\circ} \mathrm{F}$, $\mathrm{LWC}=0.75 \mathrm{~g} / \mathrm{m}^{3}, \mathrm{MVD}=20 \mu \mathrm{m}, \tau=5 \mathrm{~min}$. Scale of ruler is in centimeters, smallest division 1 millimeter.

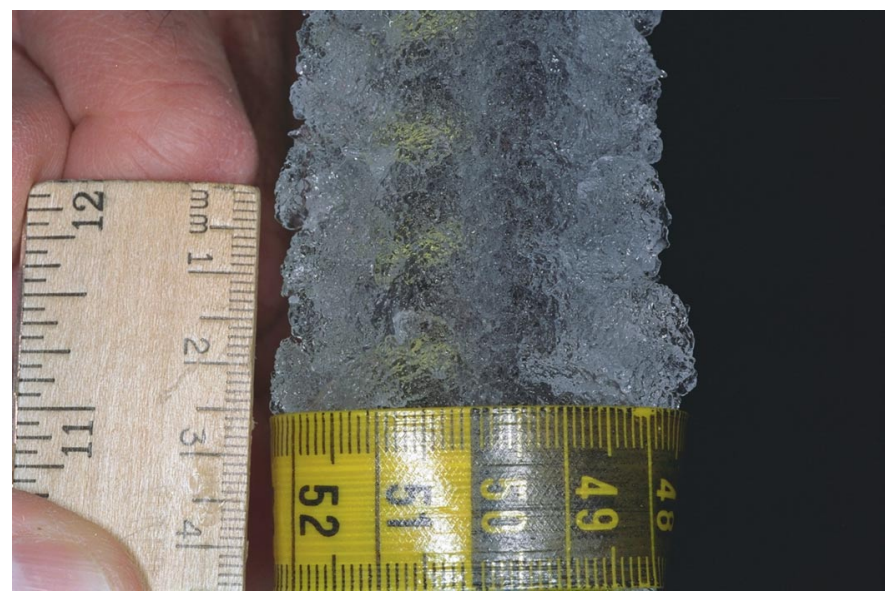

Figure 50. Front view of ice accretion showing the ice of the attachment line zone covering the glaze ice feathers zone. $\Lambda=10^{\circ}, V=200$ $\mathrm{mph}, \mathrm{T}=25^{\circ} \mathrm{F}, \quad \mathrm{LWC}=0.75 \mathrm{~g} / \mathrm{m}^{3}, \quad \mathrm{MVD}=20 \mu \mathrm{m}$, $\tau=5 \mathrm{~min}$. Direction of flow is from bottom to top, scale of ruler is in centimeters, smallest division 1 millimeter. 


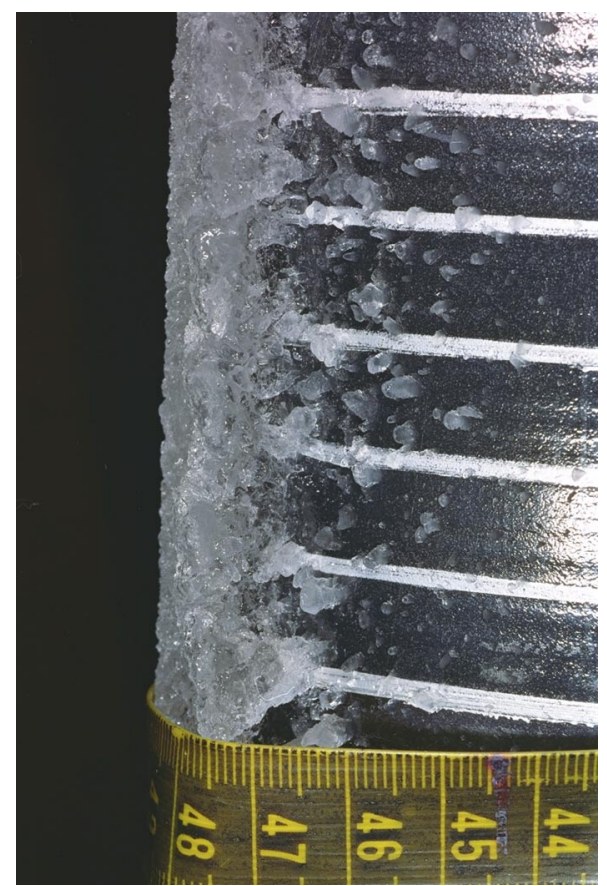

Figure 51. Side view of ice accretion showing the ice of the attachment line zone completely covering the feathers in the glaze ice feathers zone. $\Lambda=10^{\circ}, \quad \mathrm{V}=200 \mathrm{mph}, \quad \mathrm{T}=25^{\circ} \mathrm{F}$, $\mathrm{LWC}=0.75 \mathrm{~g} / \mathrm{m}^{3}, \mathrm{MVD}=20 \mu \mathrm{m}, \tau=5 \mathrm{~min}$. Direction of flow is from bottom to top, scale of ruler is in centimeters, smallest division 1 millimeter.

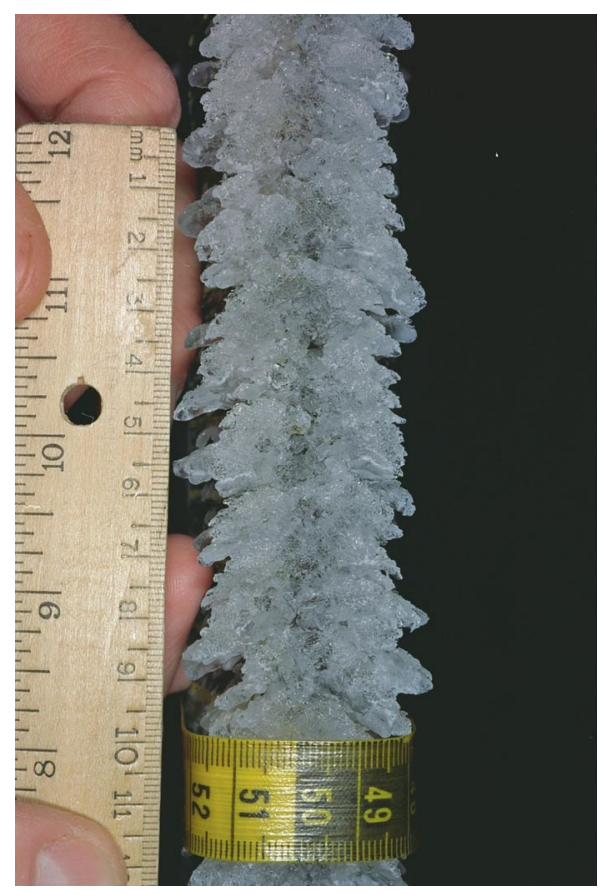

Figure 53. Front view of ice accretion showing complete scallops. $\Lambda=40^{\circ}, V=200 \mathrm{mph}$, $\mathrm{T}=25^{\circ} \mathrm{F}, \mathrm{LWC}=0.75 \mathrm{~g} / \mathrm{m}^{3}, \mathrm{MVD}=20 \mu \mathrm{m}, \tau=5 \mathrm{~min}$. Direction of flow is from bottom to top, scale of ruler is in centimeters, smallest division 1 millimeter.

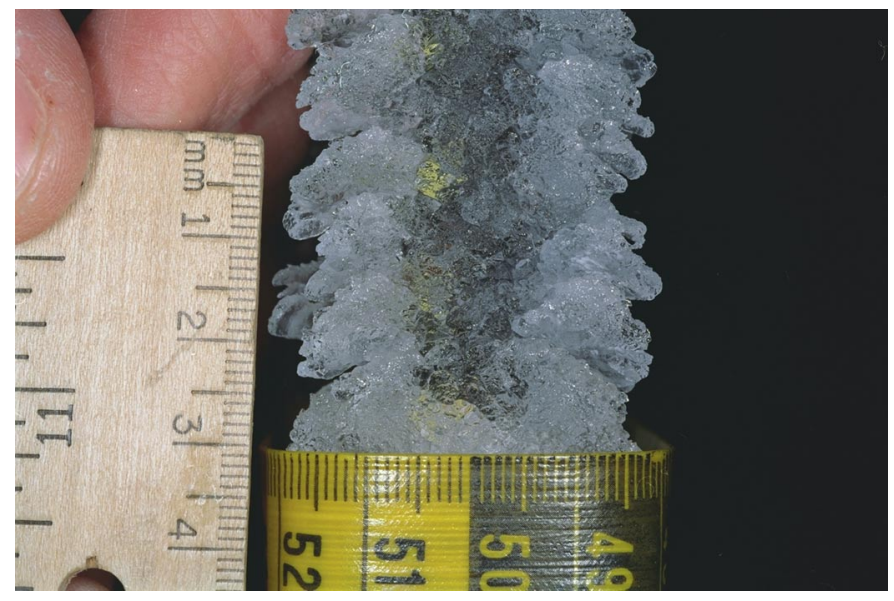

Figure 52. Front view of ice accretion showing scallop tips. $\Lambda=35^{\circ}, V=200 \mathrm{mph}, \mathrm{T}=25^{\circ} \mathrm{F}$, $\mathrm{LWC}=0.75 \mathrm{~g} / \mathrm{m}^{3}, M V D=20 \mu \mathrm{m}, \tau=5 \mathrm{~min}$. Direction of flow is from bottom to top, scale of ruler is in centimeters, smallest division 1 millimeter.

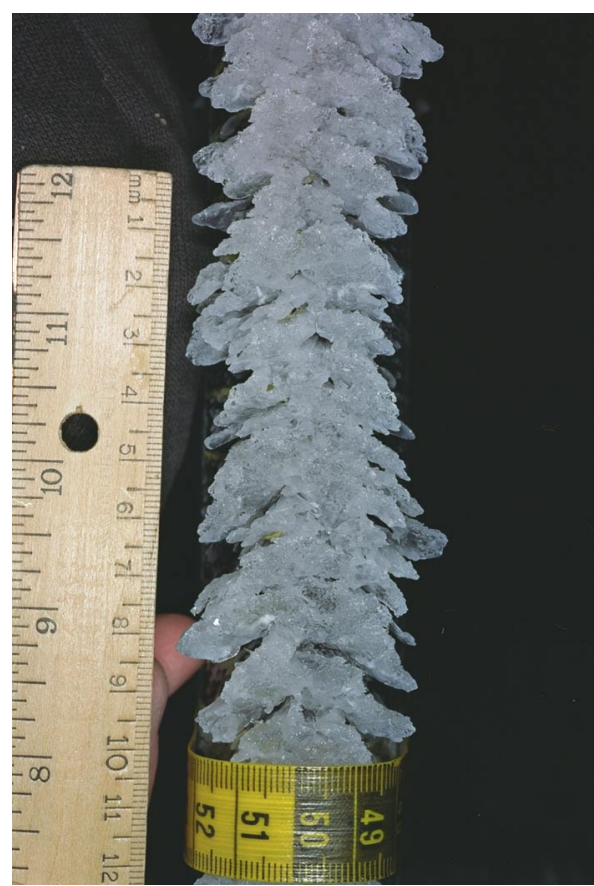

Figure 54. Complete scallops at $\Lambda=45^{\circ}$ $\mathrm{V}=200 \quad \mathrm{mph}, \quad \mathrm{T}=25^{\circ} \mathrm{F}, \quad \mathrm{LWC}=0.75 \mathrm{~g} / \mathrm{m}^{3}$, $M V D=20 \mu \mathrm{m}, \tau=5 \mathrm{~min}$. Direction of flow is from bottom to top, upper scale of ruler is in centimeters, smallest division 1 millimeter. 


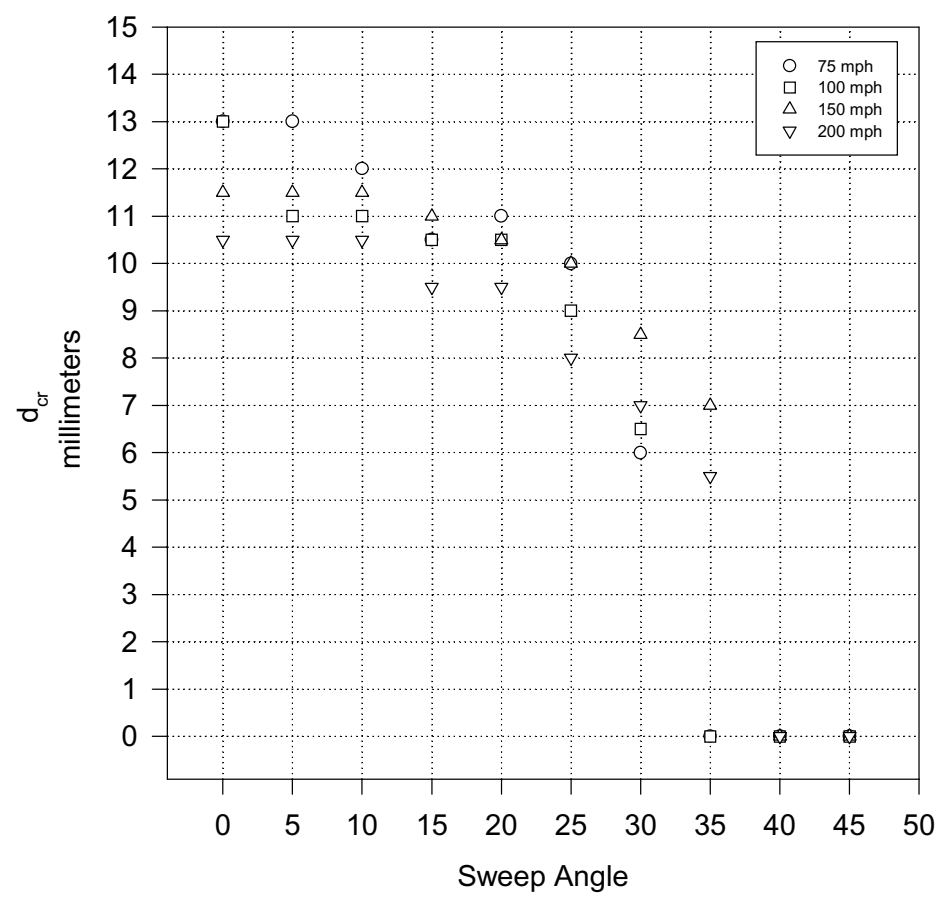

Figure 55. Change in critical distance with sweep angle for velocities of $75,100,150$ and $200 \mathrm{mph}$. $\Lambda=0^{\circ}$ to $45^{\circ}$ at $5^{\circ}$ increments, $\mathrm{T}=25^{\circ} \mathrm{F}, \mathrm{LWC}=0.8 \mathrm{~g} / \mathrm{m}^{3}, \mathrm{MVD}=20 \mu \mathrm{m}, \tau=5 \mathrm{~min}$.

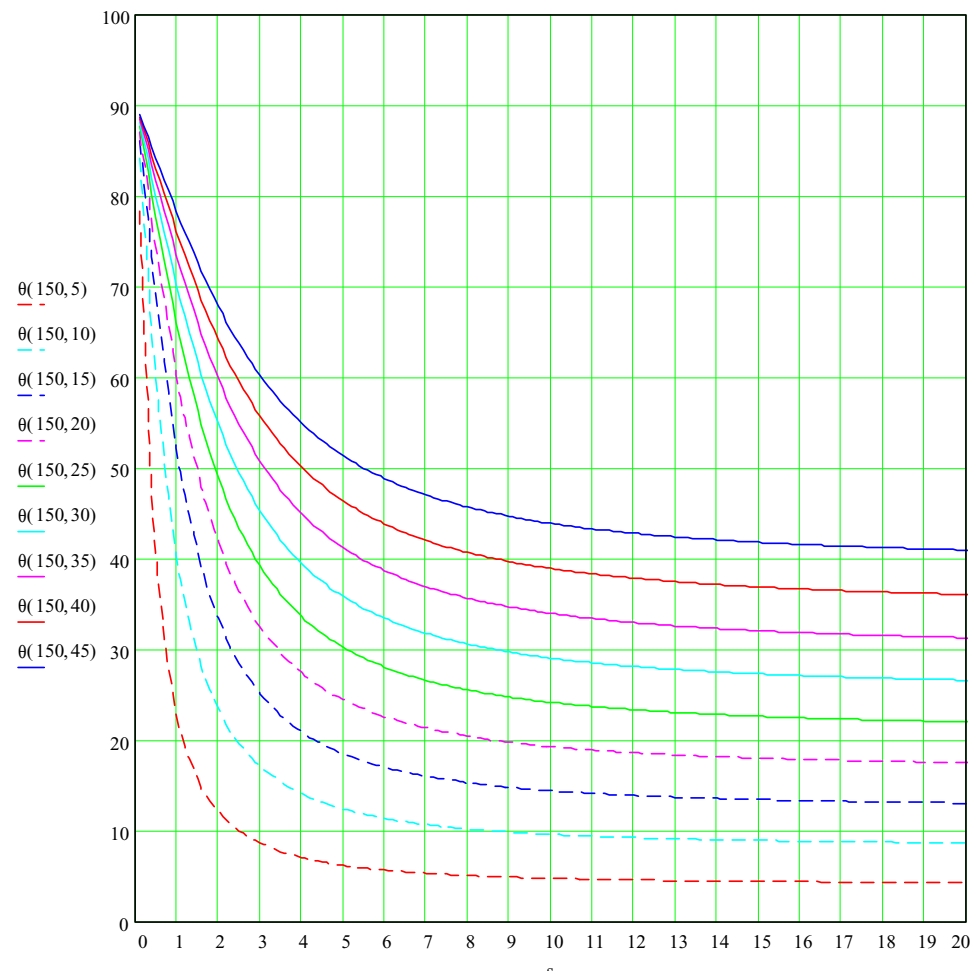

Figure 56. Angle $\theta$ in degrees, that the preferred direction of growth of the feathers makes with respect to the attachment line direction, versus the distance $s$ from the attachment line, for sweep angles from $5^{\circ}$ to $45^{\circ}$ at $5^{\circ}$ increments. The distance $s$ is in millimeters. 


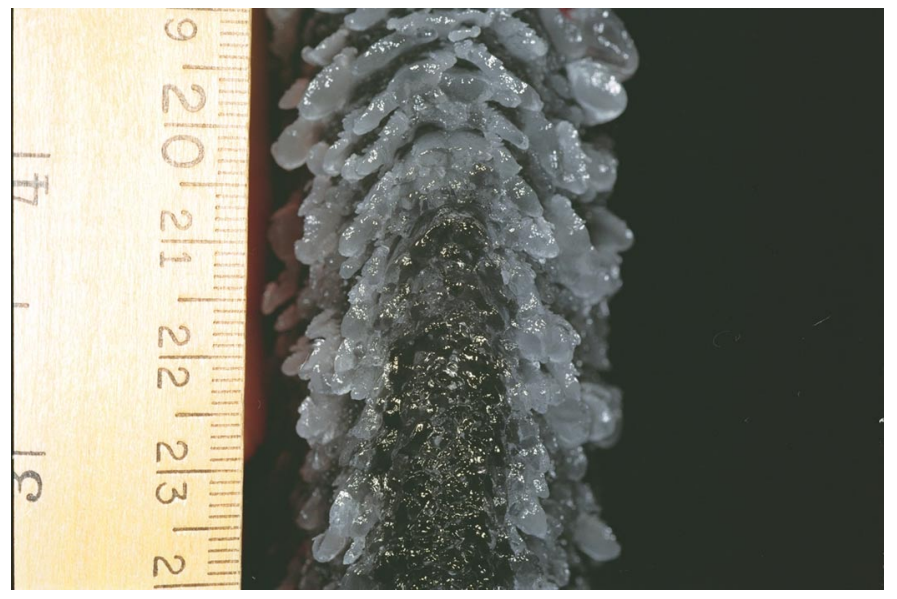

Figure 57. Front view of the beginning of the end cap showing the effect of the local sweep angle on the ice accretion. $\Lambda=20^{\circ}, V=150 \mathrm{mph}$, $\mathrm{T}=25^{\circ} \mathrm{F}, \mathrm{LWC}=0.5 \mathrm{~g} / \mathrm{m}^{3}, \mathrm{MVD}=20 \mu \mathrm{m}, \tau=5 \mathrm{~min}$. Direction of flow is from bottom to top, scale of ruler is in centimeters, smallest division 1 millimeter.

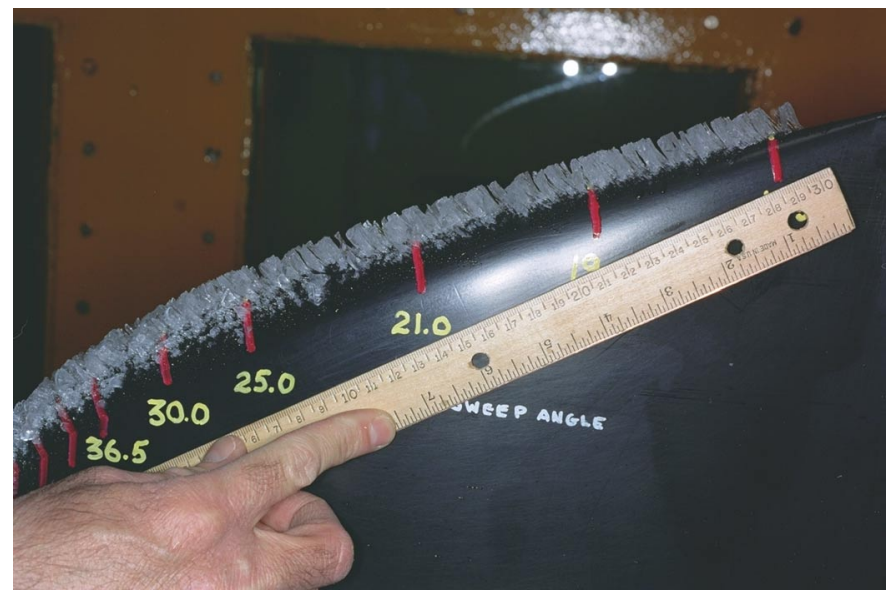

Figure 58. Side view of the end cap showing scallop formations along its length. $\Lambda=0^{\circ}$, $\mathrm{V}=150 \quad \mathrm{mph}, \quad \mathrm{T}=25^{\circ} \mathrm{F}, \quad \mathrm{LWC}=0.75 \mathrm{~g} / \mathrm{m}^{3}$, $M V D=20 u m, \tau=5 \mathrm{~min}$. Direction of flow is from left to right, upper scale of ruler is in centimeters, smallest division 1 millimeter. The numbers on the grid painted on the airfoil are equal to $90^{\circ}$ minus the local sweep angle at that location. The last red grid mark on the right corresponds to a local sweep angle of 72.5 degrees.

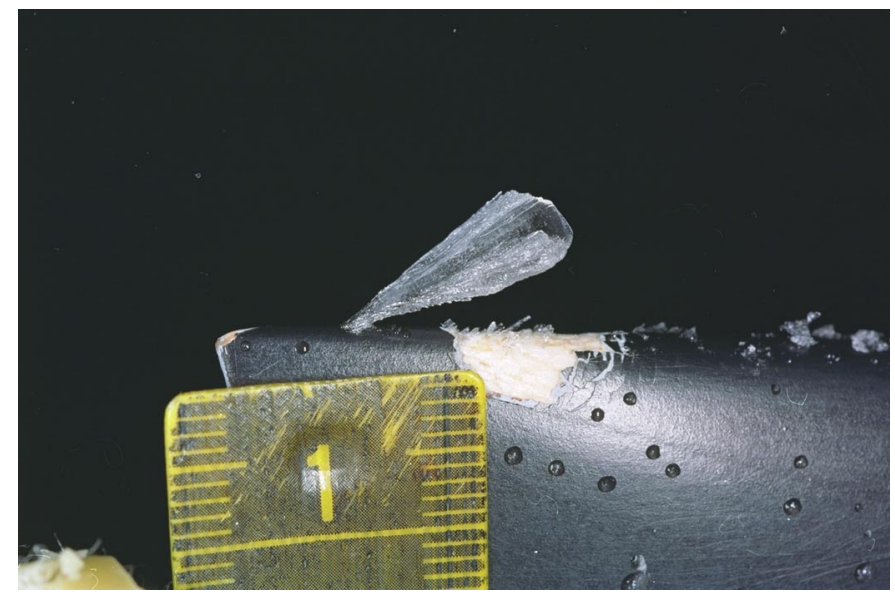

Figure 59. Side view of a single scallop at the end of the end cap. $\Lambda=10^{\circ}, V=75 \mathrm{mph}$, $\mathrm{T}=25^{\circ} \mathrm{F}, \mathrm{LWC}=0.8 \mathrm{~g} / \mathrm{m}^{3}, \mathrm{MVD}=20 \mu \mathrm{m}, \tau=10 \mathrm{~min}$. Direction of flow is from right to left, scale of ruler is in centimeters, smallest division is 1 millimeter. 
Public reporting burden for this collection of information is estimated to average 1 hour per response, including the time for reviewing instructions, searching existing data sources, gathering and maintaining the data needed, and completing and reviewing the collection of information. Send comments regarding this burden estimate or any other aspect of this collection of information, including suggestions for reducing this burden, to Washington Headquarters Services, Directorate for Information Operations and Reports, 1215 Jefferson Davis Highway, Suite 1204, Arlington, VA 22202-4302, and to the Office of Management and Budget, Paperwork Reduction Project (0704-0188), Washington, DC 20503.

\begin{tabular}{|l|l|l|}
\hline 1. AGENCY USE ONLY (Leave blank) & $\begin{array}{c}\text { 2. REPORT DATE } \\
\text { June } 1999\end{array}$ & $\begin{array}{r}\text { 3. REPORT TYPE AND DATES COVERED } \\
\text { Technical Memorandum }\end{array}$ \\
\hline
\end{tabular}

4. TITLE AND SUBTITLE 5. FUNDING NUMBERS

Parametric Experimental Study of the Formation of Glaze Ice Shapes on Swept Wings

6. $\operatorname{AUTHOR(S)}$

WU-548-20-23-00

Mario Vargas and Eli Reshotko

7. PERFORMING ORGANIZATION NAME(S) AND ADDRESS(ES)

National Aeronautics and Space Administration

John H. Glenn Research Center at Lewis Field

Cleveland, Ohio 44135-3191

8. PERFORMING ORGANIZATION REPORT NUMBER

E-11499

9. SPONSORING/MONITORING AGENCY NAME(S) AND ADDRESS(ES)

National Aeronautics and Space Administration

Washington, DC 20546-0001

10. SPONSORING/MONITORING AGENCY REPORT NUMBER

NASA TM-1999-208900

AIAA-98-0094

\section{SUPPLEMENTARY NOTES}

Prepared for the 37th Aerospace Sciences Meeting \& Exhibit sponsored by the American Institute of Aeronautics and Astronautics, Reno, Nevada, January 11-14, 1999. Mario Vargas, NASA Glenn Research Center; Eli Reshotko, Case Western Reserve University, Cleveland, Ohio. Responsible person, Mario Vargas, organization code 5840,

(216) 433-2064.

12a. DISTRIBUTION/AVAILABILITY STATEMENT

12b. DISTRIBUTION CODE

Unclassified - Unlimited

Subject Categories: 01 and 34

Distribution: Nonstandard

This publication is available from the NASA Center for AeroSpace Information, (301) 621-0390.

\section{ABSTRACT (Maximum 200 words)}

An experiment was conducted to study the effect of velocity and sweep angle on the critical distance in ice accretion formation on swept wings at glaze ice conditions. The critical distance is defined as the distance from the attachment line to the beginning of the zone where roughness elements develop into glaze ice feathers. Icing runs were performed on a NACA 0012 swept wing tip at velocities of 75, 100, 150, and 200 miles per hour. At each velocity and tunnel condition, the sweep angle was changed from $0^{\circ}$ to $45^{\circ}$ at $5^{\circ}$ increments. Casting data, ice shape tracings, and close-up photographic data were obtained. The results showed that at given velocity and tunnel conditions, as the sweep angle is increased from $0^{\circ}$ to $25^{\circ}$, the critical distance slowly decreases. As the sweep angle is increased past $25^{\circ}$, the critical distance starts decreasing more rapidly. For 75 and $100 \mathrm{mph}$ it reaches a value of 0 millimeters at $35^{\circ}$. For 150 and $200 \mathrm{mph}$ it reaches a value of 0 millimeters at $40^{\circ}$. On the ice accretion, as the sweep angle is increased from $0^{\circ}$ to $25^{\circ}$, the extent of the attachment line zone slowly decreases. In the glaze ice feathers zone, the angle that the preferred direction of growth of the feathers makes with respect to the attachment line direction increases. But overall, the ice accretions remain similar to the $0^{\circ}$ sweep angle case. As the sweep angle is increased above $25^{\circ}$, the extent of the attachment line zone decreases rapidly and complete scallops form at $35^{\circ}$ sweep angle for 75 and $100 \mathrm{mph}$, and at $40^{\circ}$ for 150 and $200 \mathrm{mph}$.

14. SUBJECT TERMS

Ice formation; Swept wings; Cross flow; Instability

36

16. PRICE CODE $\mathrm{A} 03$

\begin{tabular}{|c|c|c|}
\hline $\begin{array}{c}\text { 17. SECURITY CLASSIFICATION } \\
\text { OF REPORT } \\
\text { Unclassified }\end{array}$ & $\begin{array}{c}\text { 18. SECURITY CLASSIFICATION } \\
\text { OF THIS PAGE } \\
\text { Unclassified }\end{array}$ & $\begin{array}{c}\text { 19. SECURITY CLASSIFICATION } \\
\text { OF ABSTRACT } \\
\text { Unclassified }\end{array}$ \\
\hline
\end{tabular}

NSN 7540-01-280-5500
Standard Form 298 (Rev. 2-89)

Prescribed by ANSI Std. Z39-18 298-102 